Full Length Article

\title{
The thermal degradation of lignocellulose biomass with an acid leaching pre-treatment using a H-ZSM-5/Al-MCM-41 catalyst mixture
}

\author{
Devy K. Ratnasari ${ }^{\mathrm{a}, *}$, Antonia Horn ${ }^{\mathrm{b}}$, Thomas Brunner ${ }^{\mathrm{b}}$, Weihong Yang ${ }^{\mathrm{a}}$, Pär G. Jönsson ${ }^{\mathrm{a}}$ \\ ${ }^{\text {a }}$ KTH-Royal Institute of Technology, Brinellvägen 23, 10044 Stockholm, Sweden \\ ${ }^{\mathrm{b}}$ BIOS BIOENERGIESYSTEME GmbH, Inffeldgasse 21b, A-8010 Graz, Austria
}

\section{A R T I C L E I N F O}

\section{Keywords:}

Activation energy

Catalyst

Lignocellulose

Leaching

Thermogravimetry

\begin{abstract}
A B S T R A C T
Improvements on the pyrolysis process of biomass fuels are needed to obtain a high-quality of bio-oil. Pretreatment by acid leaching prior to the pyrolysis process is considered to remove Alkali and Alkaline Earth Metal (AAEM) from the biomass, since AAEM adversely affect the catalytic pyrolysis process. Therefore, the main objective of the present work was to determine and compare the effect of mixed-catalysts consisting of H-ZSM-5 and Al-MCM-41, which are used at different ratios in lignocellulose biomass pyrolysis via Thermal Gravimetric Analysis (TGA) for both, un-leached and leached biomass. In addition, the activation energies have been determined based on the solid-state reaction mechanism. The results from the acid leaching treatment showed that the optimum leaching process was set to $30 \mathrm{~min}, 30^{\circ} \mathrm{C}$ and $5 \mathrm{wt} \%$ acetic acid in the leaching liquid. This resulted in 59\%, 95\%, 99\%, and 96\% reduction degree of Calcium (Ca), Magnesium (Mg), Potassium or Kalium (K), and Natrium (Na), respectively. The Higher Heating Values (HHVs) for un-leached and leached biomass were 19.42 and $19.14 \mathrm{MJ} / \mathrm{kg}$, respectively, calculated by using the Milne formula. The HHV value is not significantly influenced by the acid-leaching pre-treatment. Thermogravimetric analysis showed similar trends for the mass loss as a function of temperature and four stages could be determined from the thermal degradation of biomass. There was no significant shift in the temperature profiles between un-leached and leached biomass degradations. However, the removal of AAEM significantly affected the degradation of hemicellulose, cellulose, and lignin. A 12.4-18.2\% increase of mass losses could be found in Phase 2 for leached biomass, compared to un-leached biomass. The mass losses in Phase 2 also increased with increased heating rates. From the un-leached biomass experiments using a catalyst mixture, the percentage of mass loss increased from $64.95 \mathrm{wt} \%$ at $10 \mathrm{~K} \mathrm{~min}^{-1}$ to $68.33 \mathrm{wt} \%$ at $50 \mathrm{~K} \mathrm{~min}^{-1}$. Moreover, for the leached biomass, it rose from $65.71 \mathrm{wt} \%$ at $10 \mathrm{~K} \mathrm{~min}^{-1}$ to $66.73 \mathrm{wt}$ $\%$ at $30 \mathrm{~K} \mathrm{~min}^{-1}$, before decreasing to $62.44 \mathrm{wt} \%$ at $50 \mathrm{Kmin}^{-1}$. A lower mass loss in Phase 4 for leached biomass compared to un-leached biomass showed the influence of an AAEM removal. The second order (F2) mechanism was able to illustrate the catalytic pyrolysis process, proven by the result that the coefficient of determination $\left(\mathrm{R}^{2}\right)$ was higher than 0.99 , which was high compared to other mechanisms. An acid leaching pretreatment led to a reduction in the activation energies. The activation energies for the un-leached biomass were 26.94 and $25.56 \mathrm{~kJ} \mathrm{~mol}^{-1}$ at a heating rate of $10 \mathrm{~K} \mathrm{~min}^{-1}$ for a process without and with a catalyst mixture, respectively. The activation energies for leached biomass were 24.05 and $21.80 \mathrm{~kJ} \mathrm{~mol}^{-1}$. The results also showed that the use of the acid leaching process as a treatment prior to catalytic pyrolysis is positive, since it resulted in high devolatilization and reaction rate.
\end{abstract}

\section{Introduction}

The emissions of carbon dioxide from fossil fuels and industry rose by 1.6 percent from 35.7 gigatons $\mathrm{CO}_{2}$ in 2016 to 36.2 gigatons $\mathrm{CO}_{2}$ in 2017. Further, the Global Carbon Project reported 2.7 percent increase in 2018, giving a record 37.1 gigatons $\mathrm{CO}_{2}$ [1]. Displacing fossil fuels with a low-carbon fuel or energy source is one of the ways to reverse the upward trend in $\mathrm{CO}_{2}$ emissions. Worldwide, the growth in renewable energies is encouraging [2]. Biomass is considered to be one of the replacement options with a $14 \%$ contribution towards the world annual energy consumption [3], in comparison to coal and gases with $12 \%$ and $15 \%$ contributions, respectively [4]. In addition, biomass as renewable source is able to reduce the emission of carbon dioxide as a greenhouse gas [5]. The production of bio-oil, also known as biofuel, from biomass

\footnotetext{
* Corresponding author.

E-mail address: dkra@kth.se (D.K. Ratnasari).
} 
can alleviate the demand for petroleum products [6] and contribute to decarbonisation, especially for the transport sector [7].

The lignocellulose biomass is recognized for its availability to cover the global energy demand [8]. It is also known as scalable, economically viable, and potential carbon neutral feedstock for the production of bio-oil [9]. Thermochemical conversion is known as a method to convert the lignocellulose biomass into liquids, gas fuels, and high-value chemicals [10]. One of the most promising methods that directly can produce bio-oil from lignocellulose biomass is pyrolysis. The pyrolysis process runs in the absence of oxygen. However, the resulted bio-oil from a pyrolysis process contains high oxygenated compounds. Also, the physicochemical properties of the liquid are acidic and thermally unstable, which limits its application in engines and traditional refineries [11]. Therefore, it is advantageous to use catalysts in the pyrolysis process to get a high-quality bio-oil [12].

In order to decrease the content of oxygenated compounds in the bio-oil, zeolites and mesoporous catalysts can be used [13,14]. Numerous researchers [15-19] studied the catalytic pyrolysis of lignocellulose biomass using ZSM- 5 and found that ZSM-5 promoted the deoxygenation forming aromatic hydrocarbons [12]. These findings imply that the quality of pyrolysis oil can be upgraded by introducing ZSM-5 in the pyrolysis process. However, due to its porosity, ZSM-5 is not able to break down the heavier oxygenates [20]. The larger molecules from lignin cannot penetrate the internal structure of ZSM-5 and leads to a coke formation. Further, the coke deposition will degrade the catalytic performance of ZSM-5.

As a comparison to the catalytic activity of ZSM-5, Al-MCM-41 as a mesoporous catalyst can facilitate the cracking of large molecules. However, the selectivity to aromatic compounds decrease due to the lack of micropores and the presence of large pores [20]. Hence, studies of catalyst selection and preparation methods remain broad, but the current paper focuses on the application of ZSM- 5 and Al-MCM-41. The addition of ZSM-5 and Al-MCM-41 in the pyrolysis of lignocellulose biomass has the potential to break down the large molecules from biomass and resulted in high yield of organic liquid with the increasing quantity of phenols and hydrocarbons [20-26].

On the other hand, inorganic contaminants and ash species contained in lignocellulose biomasses have shown a point of consideration in thermochemical conversion. This is due to these compounds will adversely affect the catalytic pyrolysis process, catalyze undesired dehydration reactions during the pyrolysis process $[27,28]$, as well as increase the yields of thermally derived char and non-condensable gases [29-31]. Therefore, the chemical pre-processing step, such as a dilute-acid leaching method, is preferred before the thermochemical process. The leaching process is expected to remove physiological ash components, alkali earth, and alkali metals that inhibit the thermochemical conversion [32,33]. Several attempts [34-36] have been made to investigate the aqueous fraction of pyrolytic liquids, including wood-derived acids, for demineralization of biomass. Acetic acid was chosen as a model compound for the biomass leaching process, since it is a major acid resulting from biomass pyrolysis $[34,37,38]$. Hence, the leached lignocellulose biomass is seen as a potential feedstock in the conversion of biomass to bio-oil.

A kinetic study has been conducted in order to have a better understanding of the catalytic performance of materials. Furthermore, a correct design and product yield control will be achieved by obtaining an increase knowledge of the kinetic process [39]. The reaction rates and activation energy can be determined by investigating some variables, such as temperature and the absence or the presence of catalysts $[40,41]$. Thermogravimetric analysis (TGA) is one of the techniques to determine the kinetic parameters and predict the thermal behaviors of lignocellulose biomass pyrolysis and catalytic pyrolysis [42,43]. TGA is known as a general approach to study the kinetic of decompositions since it has a great virtue of accuracy and the weight loss of the tested sample and reaction temperature are recorded continuously [44].

Over decades, there is vast literature on kinetic evaluation methods of thermal analysis for biomass pyrolysis [40,45-48]. Zakrzewski [49] investigated the degradation of beech wood and its Ea (activation energy) for different kinetic models using data from thermogravimetric experiments. It was found that the diffuse kinetic models D3 and D4 were comparable with the experimental data, giving the activation energies of 175.8 and $168.3 \mathrm{~kJ} \mathrm{~mol}^{-1}$, respectively [49]. Thermogravimetric-mass spectrometric analysis on combustion of xylan from beech wood was attempted by López-González, et al. [3]. They found the activation energies for xylan from beech wood were 128 and $125 \mathrm{~kJ} \mathrm{~mol}^{-1}$ when using heating rates of 10 and $20 \mathrm{~K} \mathrm{~min}^{-1}$, respectively [3]. Another study by Boukaous, et al. [50] examined the activation energy from the combustion of beech wood. They obtained an activation energy of $99.26 \mathrm{~kJ} \mathrm{~mol}^{-1}$ for the temperature range of $245-339{ }^{\circ} \mathrm{C}$ and $79.51 \mathrm{~kJ} \mathrm{~mol}^{-1}$ for $431-437^{\circ} \mathrm{C}$ [50]. The different kinetic parameter values and conclusions were obtained through various operational conditions and models.

Previous studies by the authors $[21,51]$ have primarily concentrated on the pyrolysis, the quality of products, as well as the kinetic aspects of un-treated biomass. There is a lack in the literature on kinetic studies of treated lignocellulose biomass using leaching. Moreover, for catalytic pyrolysis using a mixture of H-ZSM-5 and Al-MCM-41. Therefore, this study aimed to reduce the contents of the alkaline metals $(\mathrm{K}, \mathrm{Na})$ and alkaline earth metals $(\mathrm{Ca}, \mathrm{Mg}$ ) in the biomass as well as determine and compare the effect of a mixed-catalysts consisting of H-ZSM-5 and AlMCM-41, which were used at different ratios in a lignocellulose biomass pyrolysis via TGA using both un-leached and leached biomass. This paper also presents the kinetic parameters, i.e. activation energies (Ea), calculated using the Arrhenius equation. Furthermore, the solid-state reaction mechanisms from nucleation models to reaction-order models have also been put into consideration to determine the effective mechanism for a catalytic pyrolysis of lignocellulose biomass using a mixture of H-ZSM-5 and Al-MCM-41.

\section{Materials and methods}

\subsection{Lignocellulose biomass and catalysts}

Lignocellulose biomass originating from beech wood was purchased from J. RETTENMAIER \& SÖHNE GmbH + Co KG, Germany with a particle size of $300-500 \mu \mathrm{m}$. The powder catalysts of H-ZSM-5 and AlMCM-41 were obtained from Alfa Aesar, Germany, and Nankai University Catalyst Plan, China, respectively.

\subsection{Methods}

\subsubsection{Catalysts characterization}

Prior to the catalyst characterization, the catalysts were calcined in a muffle furnace at $550{ }^{\circ} \mathrm{C}$ for $15 \mathrm{~h}$ and then dried in an oven at $110^{\circ} \mathrm{C}$ for $12 \mathrm{~h}$. The samples were outgassed at $250^{\circ} \mathrm{C}$ for $3 \mathrm{~h}$ under vacuum before the measurements. A micromeritics ASAP 2020 instrument was used to measure the $\mathrm{N}_{2}$ adsorption-desorption and the BrunauerEmmett-Teller (BET) method was used to determine the surface area. Also, the micropore volume was obtained from the t-plot method. The physicochemical properties of the catalysts are shown in Table 1.

\subsubsection{Physicochemical composition of lignocellulose biomass}

The samples were prepared according to the EN ISO 14780 standard

Table 1

Properties of H-ZSM-5 and Al-MCM-41 catalysts.

\begin{tabular}{llll}
\hline Catalyst & $\begin{array}{l}\text { Si:Al ratio } \\
\text { (SAR) }\end{array}$ & $\begin{array}{l}\text { BET Surface Area } \\
\left(\mathrm{m}^{2} \mathrm{~g}^{-1}\right)\end{array}$ & $\begin{array}{l}\text { Micropore Volume } \\
\left(\mathrm{cm}^{3} \mathrm{~g}^{-1}\right)\end{array}$ \\
\hline HZSM-5 & 30 & 314.7320 & 0.1492 \\
Al-MCM-41 & 25 & 957.5100 & -
\end{tabular}


Table 2

Results of the test runs with different acetic acid concentrations and different temperatures at a 1/s-ratio of 10:1.

\begin{tabular}{|c|c|c|c|c|c|c|c|c|}
\hline \multirow[t]{2}{*}{ Experiment Condition } & \multicolumn{4}{|c|}{ Element Content (mg/kg d.b.*) } & \multicolumn{4}{|c|}{ Leaching Efficiency** (wt\%) } \\
\hline & $\mathrm{Ca}$ & $\mathrm{Mg}$ & $\mathrm{K}$ & $\mathrm{Na}$ & $\mathrm{Ca}$ & $\mathrm{Mg}$ & $\mathrm{K}$ & $\mathrm{Na}$ \\
\hline Un-leached lignocellulose & 1790 & 385 & 1020 & 54 & & & & \\
\hline \multicolumn{9}{|c|}{$\begin{array}{l}\text { A temperature of } 90^{\circ} \mathrm{C}, \\
\text { a residence time of } 120 \mathrm{~min} \text {, } \\
\text { Acetic acid in leaching liquid: }\end{array}$} \\
\hline $10 \mathrm{wt} \%$ & $717 \pm 42$ & $10.1 \pm 0.9$ & $11.1 \pm 1.6$ & $<2.0$ & $60 \pm 2$ & $97 \pm<0.1$ & $99 \pm<0.1$ & $>96$ \\
\hline $5 \mathrm{wt} \%$ & $739 \pm 45$ & $16.1 \pm 0.5$ & $14.4 \pm 3.2$ & $2.4 \pm 0.4$ & $59 \pm 3$ & $96 \pm 0.1$ & $99 \pm<0.1$ & $96 \pm 1.0$ \\
\hline $1 \mathrm{wt} \%$ & $987 \pm 18$ & $43.7 \pm 1.8$ & $13.9 \pm 0.9$ & $2.1 \pm<0.1$ & $45 \pm 1$ & $89 \pm<0.1$ & $99 \pm<0.1$ & $96 \pm 0.1$ \\
\hline $0.3 \mathrm{wt} \%$ & $1098 \pm 103$ & $82.6 \pm 5.0$ & $34.2 \pm 11.1$ & $<2.0$ & $39 \pm 6$ & $79 \pm 1.0$ & $97 \pm 1.0$ & $>96$ \\
\hline \multicolumn{9}{|c|}{$\begin{array}{l}\text { A residence time of } 30 \mathrm{~min} \text {, } \\
10 \mathrm{wt} \% \text { acetic acid in leaching liquid, with temperatures } \\
\text { of: }\end{array}$} \\
\hline $30{ }^{\circ} \mathrm{C}$ & $716 \pm 16.6$ & $14.0 \pm 0.2$ & $11.5 \pm 0.4$ & $<1.6$ & $60 \pm 0.9$ & $96 \pm 0.1$ & $99 \pm<0.1$ & $>97$ \\
\hline $60{ }^{\circ} \mathrm{C}$ & $639 \pm 66.2$ & $12.7 \pm 0.6$ & $11.8 \pm 0.5$ & $<1.6$ & $64 \pm 3.7$ & $97 \pm 0.2$ & $99 \pm<0.1$ & $>97$ \\
\hline $90^{\circ} \mathrm{C}$ & $725 \pm 4.6$ & $10.5 \pm 0.3$ & $10.7 \pm 0.5$ & $<1.6$ & $59 \pm 0.3$ & $97 \pm 0.1$ & $99 \pm<0.1$ & $>97$ \\
\hline \multicolumn{9}{|c|}{$\begin{array}{l}\text { A residence time of } 30 \mathrm{~min} \text {, } \\
5 \mathrm{wt} \% \text { acetic acid in leaching liquid, with temperatures of: }\end{array}$} \\
\hline $30^{\circ} \mathrm{C}$ & $739 \pm 73.5$ & $20.8 \pm 0.9$ & $14.0 \pm 1.4$ & $1.9 \pm 0.4$ & $59 \pm 4.1$ & $95 \pm 0.2$ & $99 \pm 0.1$ & $96 \pm 0.7$ \\
\hline $60^{\circ} \mathrm{C}$ & $773 \pm 9.3$ & $19.0 \pm 0.7$ & $13.3 \pm 0.5$ & $1.7 \pm 0.1$ & $57 \pm 0.5$ & $95 \pm 0.2$ & $99 \pm 0.0$ & $97 \pm 0.3$ \\
\hline $90^{\circ} \mathrm{C}$ & $783 \pm 13.6$ & $17.1 \pm 1.0$ & $12.4 \pm 0.9$ & $2.0 \pm 0.0$ & $56 \pm 0.8$ & $96 \pm 0.3$ & $99 \pm 0.1$ & $96 \pm 0.1$ \\
\hline
\end{tabular}

* d.b.: dry basis

$* *$ leaching efficiency $=(1-$ element concentration in the treated biomass/element concentration in the untreated biomass $) * 100$.

Table 3

Properties of un-leached (L1) and leached lignocellulose (L2) biomasses for TGA experiments.

\begin{tabular}{|c|c|c|}
\hline Analysis & L1 & $\mathrm{L} 2$ \\
\hline Proximate analysis & d.b. ${ }^{\mathrm{a}} w t . \%$ & d.b. ${ }^{\mathrm{a}} w t . \%$ \\
\hline Volatiles & 84.2 & 88.3 \\
\hline Moisture & 14.1 & 4.3 \\
\hline Ash & 0.8 & 0.30 \\
\hline Fixed carbon ${ }^{\mathrm{b}}$ & 0.9 & 7.1 \\
\hline Ultimate analysis & d.b. ${ }^{\mathrm{a}} w t . \%$ & d.b. ${ }^{\mathrm{a}} w t . \%$ \\
\hline Carbon (C) & 48.5 & 49.1 \\
\hline Hydrogen $(\mathrm{H})$ & 6.3 & 5.9 \\
\hline Oxygen $(\mathrm{O})^{\mathrm{b}}$ & 44.65 & 44.80 \\
\hline Nitrogen (N) & $<0.10$ & 0.18 \\
\hline Sulphur (S) & 0.026 & 0.012 \\
\hline Elements & $m g / k g d . b .^{\text {a }}$ & $m g / k g d . b .^{a}$ \\
\hline Calcium (Ca) & 1790 & 739 \\
\hline Magnesium (Mg) & 385 & 20.8 \\
\hline Natrium (Na) & 54.3 & 1.9 \\
\hline Potassium (K) & 1020 & 14.0 \\
\hline
\end{tabular}

a d.b.: dry basis.

b Calculated by difference.

[52]. The moisture content of biomass was determined according to the EN ISO 18134 standard [53]. In addition, the EN ISO 16948 standard [54] was used to determine the $\mathrm{C}, \mathrm{H}$, and $\mathrm{N}$ contents. The ash content (loss of ignition at $550{ }^{\circ} \mathrm{C}$ ) was determined according to the EN ISO 18122 standard [55]. The concentrations of major and minor elements as well as of $S$ in the samples were determined by elemental analyzer LECO RC-612-C and multistep pressurized digestion of the samples, followed by detection applying inductively coupled plasma-optical emission spectroscopy (ICP-OES) (Arcos, Spectro). The chemical composition of un-leached lignocellulose biomasses (L1) is presented in Table 3.

\subsubsection{Acid leaching experiment}

The leaching was performed in aqueous solutions consisting of deionized water and acetic acid. The equipment consisted of a heated plate with a magnetic stirrer, a glass reactor (volume: $2 \mathrm{~L}$ ), a

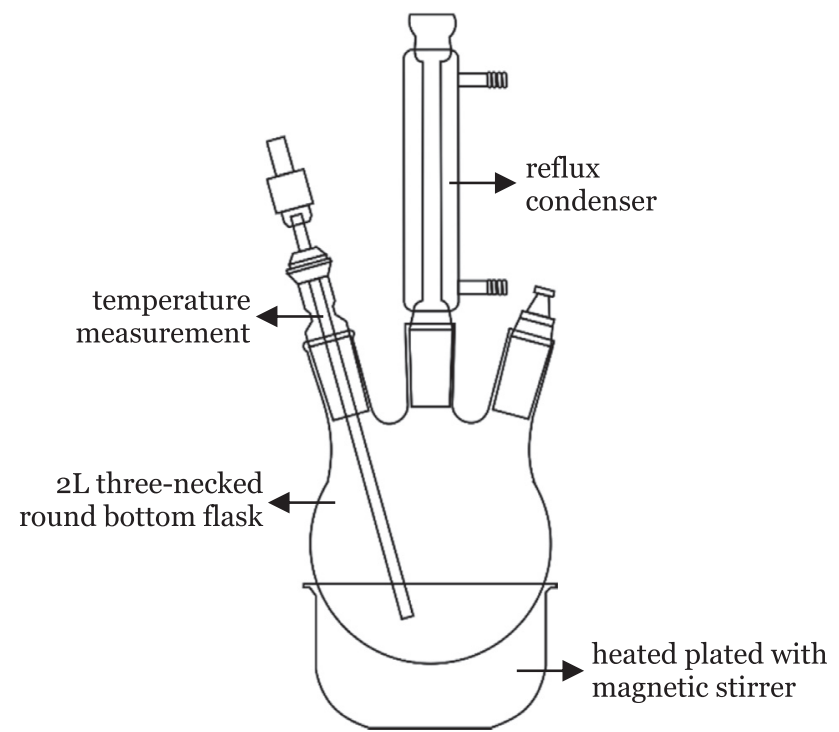

Fig. 1. Test run set-up for the acid leaching experiment.

temperature measurement device inside the reactor, and a reflux condenser to recover liquids evaporated during leaching at enhanced temperatures. A Buchner funnel and a water jet pump were used to remove the leaching liquid from the biomass. In Fig. 1, the test run setup for the leaching experiment is shown. The experiments were carried out in triplicate and standard deviation for each set of triplicates was calculated.

A leaching liquid of deionized water and acetic acid was prepared. The concentration of acetic acid in the leaching liquid was varied between 0.3 and $10 \mathrm{wt} \%$. The leaching liquid was filled into the reactor and heated up to the desired reaction temperature using a continuous stirring. Then, the biomass was added in small batches (to avoid formation of granulates) under the stirring. Also, the stirring continued for the defined residence time. Thereafter, the stirrer and the heater were shut down and the reactor was cooled down to about $30^{\circ} \mathrm{C}$ (to enable further handling). The suspension was shaken to re-suspend all solids and poured into the Buchner funnel and sucked with a water jet pump 
through the filter. Then, the Buchner funnel was filled up again with fresh (deionized) water and the water was sucked through the water jet pump to displace the acid from the biomass cake. This was repeated until a constant $\mathrm{pH}$ value of 6-7 in the liquid downstream the water jet pump was reached.

\subsubsection{TGA experiment}

Prior to TGA experiments, the sample was dried in an oven at $110^{\circ} \mathrm{C}$ overnight to reduce the water content. The samples were prepared by using fixed biomass loading and catalyst mass loading ratio (biomass: catalyst ratio of 1:1). The un-leached lignocellulose biomass was labelled L1, while the leached one was labelled L2. The variation of $\mathrm{H}$ ZSM-5:Al-MCM-41 ratios were labelled as follows: H (1:0), HA-71 (7:1), HA-31 (3:1), HA-11 (1:1), HA-13 (1:3), and A (0:1).

The experiments were carried out in a Netzsch STA 449 F3 Jupiter equipment using the TGA/DTA configuration. Approximately $60 \mathrm{mg}$ of the biomass/catalyst mixture was used for each run. A temperature program with specified heating rates, inert atmosphere flows, steam ratios and residence times were prepared with Proteus, the software of STA 449 F3 Jupiter. The following temperature program was used for each TGA run with Nitrogen $\left(\mathrm{N}_{2}\right)$ as an inert atmosphere.

- From the ambient temperature to $110^{\circ} \mathrm{C}$, at a heating rate of $10^{\circ} \mathrm{C}$ / min, for sample drying (moisture removal);

- Isothermal drying at $110^{\circ} \mathrm{C}$, for $10 \mathrm{~min}$ (until constant mass is reached);

- Temperature raising from 110 to $900{ }^{\circ} \mathrm{C}$ (for pyrolysis and subsequent release of volatiles) at different heating rates $(10,20,30$, $50{ }^{\circ} \mathrm{C} / \mathrm{min}$ ), and

- Isothermal transformation at $900{ }^{\circ} \mathrm{C}$ for $10 \mathrm{~min}$ (to enhance the devolatilization process and production of char).

From an ambient temperature to $900^{\circ} \mathrm{C}$, an argon at a flow rate of $50 \mathrm{ml} / \mathrm{min}$ was used to keep the reacting atmosphere inert. The mass loss and mass loss rate were recorded online as functions of time and temperature. The TGA experiments were carried out in duplicate and showed good reproducibility.

\subsubsection{Kinetic method}

The solid-state reaction kinetics is studied by using the change in extent of reaction $(\alpha)$.

$\alpha=\frac{m_{0}-m_{t}}{m_{0}-m_{\infty}}$

where $m_{0}, m_{t}$, and $m_{\infty}$ are the initial masses of the samples, the mass of sample at time $t$, and the mass of sample at the end of a reaction, respectively.

By using the extent of reaction, the solid-state reaction rate can be described as follows:

$\frac{d \alpha}{d t}=k(T) f(\alpha)$

The integral rate law is obtained by integrating the above equation: $g(\alpha)=k t$

Introducing the Arrhenius equation for replacing $k(T)$ will give the temperature dependence of the rate constant as the following equation:

$g(\alpha)=A \exp \left(\frac{-E_{a}}{R T}\right) t$

where $A$ and $E_{a}$ are the pre-exponential factor and activation energy, respectively. The detailed integral method is describe elsewhere [56]. The calculation of $E_{a}$ can be carried out by introducing various expressions for $g(\alpha)$ in Eq. (2). Data acquisition and data processing were carried out using Microsoft Excel. The different kinetic models for $g(\alpha)$ [41,57-62], commonly known as solid-state reaction mechanism, are listed in Supplement S1.

\section{Results and discussion}

\subsection{Leaching of alkali and alkaline earth metallic (AAEM) species}

Kesalahan! Sumber referensi tidak ditemukan. show the results of the leaching tests at different acetic acid concentrations at a liquid to solid (1/s)-ratio of $10: 1$, a temperature of $90^{\circ} \mathrm{C}$, and a residence time of $120 \mathrm{~min}$. It is apparent that a decrease of the leaching efficiency for $\mathrm{Ca}$ was observed to be connected to a reduction of the acetic acid concentrations. Leaching efficiencies of $60 \%$ and $59 \%$ and a decrease in Ca contents from $1790 \mathrm{mg} / \mathrm{kg}$ to 717 and $739 \mathrm{mg} / \mathrm{kg}$ were achieved when using $10 \mathrm{wt} \%$ and $5 \mathrm{wt} \%$ of acetic acid concentrations, respectively. Further reductions of the acetic acid concentrations led to a larger decrease in the leaching efficiencies and promoted an increase of the $\mathrm{Ca}$ contents. A leaching efficiency of $45 \%$ and a Ca content of $987 \mathrm{mg} / \mathrm{kg}$ were obtained when using a $1 \mathrm{wt} \%$ of acetic acid concentration, while an efficiency of $39 \%$ and a Ca content of $1098 \mathrm{mg} / \mathrm{kg}$ were reached when using a leaching process with a $0.3 \mathrm{wt} \%$ of acetic acid concentration. This finding provides an evidence that an acid leaching process is effective to lower the $\mathrm{Ca}$ content. As a comparison, Oudenhoven, et al. [63] investigated the leaching process for pinewood, straw, and bagasse with demineralized water and the results showed that it was only possible to remove $20 \%$ of calcium using this process [63].

A decrease of the leaching efficiencies for $\mathrm{Mg}$ content was also noticed with a reduction of the acetic acid concentrations. By using an acetic acid concentration of $10 \mathrm{wt} \%$, the leaching efficiency reached $97 \%$ with a significant reduction of the $\mathrm{Mg}$ content from $385 \mathrm{mg} / \mathrm{kg}$ to $10.1 \mathrm{mg} / \mathrm{kg}$. A leaching process using a $0.3 \mathrm{wt} \%$ acid concentration gave an efficiency of $79 \%$ as well as a $\mathrm{Mg}$ content of $82.6 \mathrm{mg} / \mathrm{kg}$. This was higher than that from a process using an acid concentration of $10 \mathrm{wt} \%$. Although the differences of the leaching efficiencies when using $10 \mathrm{wt} \%$ and $5 \mathrm{wt} \%$ acetic acid concentrations in the leaching liquid slightly differed, a strong decrease when using $1 \mathrm{wt} \%$ and $0.3 \mathrm{wt} \%$ acetic acid prevailed.

The above findings contradict the results by Davidsson, et al. [64]. They found that the removal of alkali metals ( $\mathrm{Ca}$ and $\mathrm{Mg}$ ) when using acid leaching reached $70 \%$ at temperatures below $600^{\circ} \mathrm{C}$ [64]. However, in the current study a $60 \%$ removal of $\mathrm{Ca}$ and a $97 \%$ removal of $\mathrm{Mg}$ was achieved at a temperature of $90{ }^{\circ} \mathrm{C}$. A study by Wu, et al. [65] also attained a lower percentage of Ca removal (5-30 wt\%) when using a water leaching process, as compared to the current study. Specifically, they only reached an $80 \%$ removal of the $\mathrm{Mg}$ content. The alkali earth metal ( $\mathrm{Ca}$ and $\mathrm{Mg}$ ) are hardly water-soluble [65]. Hence, higher leaching efficiencies are expected from an acid leaching compared to a water leaching. Nevertheless, the results of the current study agrees relatively well with the results of Davidsson, et al. [64] study showing that the acid leaching process does not completely remove the alkali metals. This is due to a strong bond of the compounds to the material. In the case of this study, $40 \%$ of Ca remained in the biomass after the completed leaching process.

The $\mathrm{K}$ content was reduced from $1020 \mathrm{mg} / \mathrm{kg}$ to a level below $15 \mathrm{mg} / \mathrm{kg}$, corresponding to a leaching efficiency of $99 \%$, when applying a minimum of $1 \mathrm{wt} \%$ acetic acid. The leaching efficiency decreased to $97 \%$ (on average $34.2 \mathrm{mg} / \mathrm{kg}$ ) when using a $0.3 \mathrm{wt} \%$ acetic acid. For Na, leaching efficiencies of at least $96 \%$ were achieved for all tested concentrations of acetic acid. This resulted in a reduction of the $\mathrm{Na}$ contents from $54 \mathrm{mg} / \mathrm{kg}$ to values of less than $2.4 \mathrm{mg} / \mathrm{kg}$. As compared to the leaching process with demineralized water [63], the leaching efficiency in this study was able to completely remove $\mathrm{Na}$ and $\mathrm{K}$ and reaching up to $96-99 \%$ efficiencies. Oudenhoven, et al. [63] obtained lower efficiencies than the present study, amounting to 75-90\%.

The findings of Liu and Bi [66] supports the present findings. They 
investigated the removal of $\mathrm{Ca}, \mathrm{Mg}, \mathrm{Na}$, and $\mathrm{K}$ from pine barks by acid leaching using a $0.5 \mathrm{M} \mathrm{HCl}$ solution for $48 \mathrm{~h}$ at a temperature of $20^{\circ} \mathrm{C}$. They found that the removal efficiencies for $\mathrm{Ca}, \mathrm{Mg}$, $\mathrm{Na}$, and $\mathrm{K}$ were 90 , 98,100 , and $92 \%$, respectively [65]. Although the results from the present study were lower than the findings of Liu and Bi [66], the present finding showed comparable results when using a weak acid, $\mathrm{CH}_{3} \mathrm{COOH}$, instead of a strong acid, e.g. HCl. Furthermore, the residence time was short, $2 \mathrm{~h}$, as contrasted to $48 \mathrm{~h}$ in Liu and Bi's [66] study.

The influences of the temperatures and residence times on the leaching efficiency were investigated. The residence time was set to $30 \mathrm{~min}$ for all test runs, while the temperature was varied from $30^{\circ} \mathrm{C}$ to $90^{\circ} \mathrm{C}$. The test runs were performed with acid concentrations of $10 \mathrm{wt} \%$ and $5 \mathrm{wt} \%$, to reach the leaching efficiencies, as shown in the previous tests. The results of these test runs are shown in Table 2.

As shown in Table 2, there was no significant influence of the temperature on the Ca content at a residence time of $30 \mathrm{~min}$. The leaching efficiencies varied between $59 \%$ and $64 \%$ when using a $10 \mathrm{wt}$ $\%$ of acid concentration. Accordingly, a reduction of the Ca contents was observed from $1790 \mathrm{mg} / \mathrm{kg}$ to 725 and $639 \mathrm{mg} / \mathrm{kg}$. In a process using an acid concentration of $5 \mathrm{wt} \%$, the leaching efficiency was slightly lower than using an acid concentration of $10 \mathrm{wt} \%$. The efficiency decreased with an increased temperature, from $59 \%$ with a $\mathrm{Ca}$ content of $739 \mathrm{mg} / \mathrm{kg}$ at $30^{\circ} \mathrm{C}$ to $56 \%$ with a Ca content of $783 \mathrm{mg} / \mathrm{kg}$ at $90^{\circ} \mathrm{C}$.

For $\mathrm{Mg}$, a trend of increasing leaching efficiencies with increasing temperatures was observed. In the case of a $10 \mathrm{wt} \%$ acetic acid, the $\mathrm{Mg}$ contents were reduced from $385 \mathrm{mg} / \mathrm{kg}$ to 10.5 and $14.0 \mathrm{mg} / \mathrm{kg}$ (leaching efficiencies 96-97\%). The leaching efficiencies in the process when using an acid concentration of $5 \mathrm{wt} \%$ was slightly lower, namely 95-96\%, as the $\mathrm{Mg}$ contents were reduced from 17.1 to $20.8 \mathrm{mg} / \mathrm{kg}$.

The highest leaching efficiencies for $\mathrm{K}$ was noticed at all temperatures. The $\mathrm{K}$ contents in the treated biomass decreased with the increasing temperatures, namely from $1020 \mathrm{mg} / \mathrm{kg}$ to 14.0 and $12.4 \mathrm{mg} /$ $\mathrm{kg}$ with an acid concentration of $5 \mathrm{wt} \%$ and to the range of $10.7-11.8 \mathrm{mg} / \mathrm{kg}$ with an acid concentration of $10 \mathrm{wt} \%$.

The contents of $\mathrm{Na}$ in the leached biomass were reduced from $54.3 \mathrm{mg} / \mathrm{kg}$ to below $1.6 \mathrm{mg} / \mathrm{kg}$ when using an acid concentration of $10 \mathrm{wt} \%$ at all temperatures. This resulted in leaching efficiencies of more than $97 \%$, while the Na content in a process with an acid concentration of $5 \mathrm{wt} \%$ scattered between 1.7 and $2.0 \mathrm{mg} / \mathrm{kg}$ and leaching efficiencies from $96 \%$ to $97 \%$ result.

Wigley [67], who investigated the influence of acid leaching with $1 \%$ nitric acid $\left(\mathrm{HNO}_{3}\right)$ on the torrefaction of Pinus radiata, found that $4 \mathrm{~h}$ was the minimum time for leaching of $P$. radiata. A shorter time than $4 \mathrm{~h}$ was assumed to be not sufficient to allow for the leaching solution to penetrate deeply into the biomass micropores, while a long residence time of $8 \mathrm{~h}$ gave no further reduction on the AAEM content. The present study provided an effective leaching method, giving more than a $55 \%$ of leaching efficiency for $\mathrm{Ca}$ and more than $95 \%$ efficiencies for $\mathrm{Mg}, \mathrm{K}$, and $\mathrm{Na}$ for a 30 min leaching process. Furthermore, leaching with a weak acid, $\mathrm{CH}_{3} \mathrm{COOH}$, would avoid environmental penalties, as compared to a process using strong acids, e.g. $\mathrm{HNO}_{3}$. Nonetheless, in regards to the influence of temperatures, the above results are in the lines with the results by Wigley [67]. He found that an increase of the temperature from $30^{\circ} \mathrm{C}$ to $90^{\circ} \mathrm{C}$ had no significant advantage on the reduction of the AAEM content. Moreover, that an increase of the leaching temperature to $150{ }^{\circ} \mathrm{C}$ initiated a hydrolysis reaction, which was not a desirable effect [67].

The results of the present study suggest that the reduction of the residence time to $30 \mathrm{~min}$ as well as the decrease of the temperature to $30{ }^{\circ} \mathrm{C}$ have no significant influence on the leaching efficiency for both acetic acid concentrations ( $10 \mathrm{wt} \%$ and $5 \mathrm{wt} \%$ ). The obtained leaching efficiencies from these processes were in the same range (59-99 wt\%) as the results for a residence time of $120 \mathrm{~min}$ and a temperature of $90{ }^{\circ} \mathrm{C}$.
To summarize, with respect to economic aspects, the leaching parameters to produce leached biomass for the TGA experiments were set to $30 \mathrm{~min}, 30^{\circ} \mathrm{C}$ and $5 \mathrm{wt} \%$ acetic acid in the leaching liquid. At these parameters a significant reduction of the AAEM content in the leached biomass could be achieved (Ca: 59\%, Mg: 95\%, K: 99\%, and Na: $96 \%)$.

\subsection{Physicochemical parameters}

The physicochemical analysis was carried out for the leached biomass. The results are compared to the physicochemical analysis for the un-leached biomass. As shown in Table 3, the samples contain low nitrogen $(<0.2 \mathrm{wt} \%)$ and sulfur $(<0.03 \mathrm{wt} \%)$ contents. This indicates that the risk for emission of toxic gases $\left(\mathrm{NO}_{\mathrm{x}}, \mathrm{SO}_{\mathrm{x}}\right)$ is low.

The Higher Heating Value (HHV) is used to express the calorific value of the biomass, which indicates the amount of energy available from the biomass. The value is calculated by using the Milne formula [68]. The estimated HHV values of L1 and L2 samples are 19.42 and $19.14 \mathrm{MJ} / \mathrm{kg}$, respectively. These values are higher than the HHV values of wood, which was investigated by Jahirul, et al. [69] (16 MJ/kg). A study of Acar and Ayanoglu [70] showed similar HHV values for beech wood as found in the present study. They measured the HHV values of beech wood with a bomb calorimeter according to the ASTM D2015 standard [71] and obtained a HHV value of $19.2 \mathrm{MJ} / \mathrm{kg}$ [70].

The L2 sample was expected to have higher HHV values compared to L1, as concluded by Jenkins, et al. [72], Sheng and Azevedo [73], and Jenkins, et al. [74]. This is due to the low contents of minerals in the biomass, which leads to high HHV values. The HHV value represents mass-based measurement. However, the results of the present study showed that the HHV value is not significantly influenced by the acid-leaching pre-treatment. The HHV value of leached biomass (L2) was $0.28 \mathrm{MJ} / \mathrm{kg}$ lower than the value of un-leached biomass (L1), even though it should be noted that the mineral content in L2 is clearly decreased. This is shown in Table 3 by the decreased value of ash as well as for the $\mathrm{Ca}, \mathrm{Mg}, \mathrm{Na}$, and $\mathrm{K}$ contents.

\subsection{Analysis of TG-DTG curves}

Fig. 2(a) and (b) show TG and DTG curves at different heating rates for pyrolysis of un-leached and leached lignocellulose biomass, respectively. All test runs showed similar trends with respect to the mass loss as a function of temperature. Four stages are observed for both biomasses: Phase 1, a drying stage; Phase 2, a devolatilization stage, which started approximately at $160^{\circ} \mathrm{C}$. El-Sayed, et al. [75] revealed that during this phase, cellulose and hemicellulose degradations occurred. Raveendran, et al. [76] added that the small fraction of lignin component might be given off during this phase. A Phase 3 followed approximately at $360^{\circ} \mathrm{C}$, where lignin and heavier hydrocarbons are decomposed; and Phase 4, a residual stage, where a slight mass loss up to the end temperature $\left(900^{\circ} \mathrm{C}\right)$. According to Fig. 2, the TGA and DTG curves of un-leached and leached biomass follow the usual shape for lignocellulose biomass materials [77]. This behaviour is in agreement with the previous findings $[78,79]$ during the investigation of biomass degradation under inert $\left(\mathrm{N}_{2}\right)$ atmosphere.

The important characteristic parameter for pyrolysis performance analysis are shown in Fig. 3. T-onset is defined as the start of the biomass devolatilization, determined by the extrapolation of the DTG curve. The temperature which corresponds to the maximum weight loss of hemicellulose is labelled as T-hc, while the T-peak represents the maximum mass loss rate and the corresponding temperature. When the weight of the biomass remains unchanged, the temperature represented is marked as the T-offset value. The thermal properties of lignocellulose biomass, un-leached and leached, for different heating rates are summarized in Table 4.

As shown in Table 4, the devolatilization of un-leached lignocellulose biomass starts at a temperature of $228^{\circ} \mathrm{C}$ for a heating rate 
(a) $-10 \mathrm{~K} / \mathrm{min}-20 \mathrm{~K} / \mathrm{min}-30 \mathrm{~K} / \mathrm{min}-50 \mathrm{~K} / \mathrm{min}$

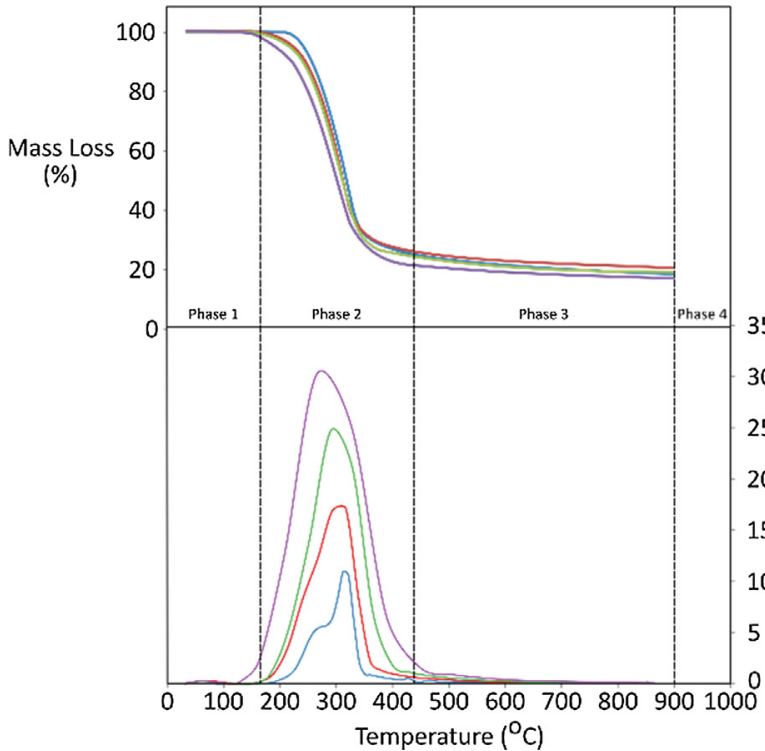

(b)

$\begin{array}{ll} \\ \\ 2 & -\mathrm{d} \alpha / \mathrm{dt} \\ (\mathrm{mg} / \mathrm{s})\end{array}$

Fig. 2. TG and DTG curves of (a) un-leached (L1) and (b) leached lignocellulose (L2) biomass at various heating rates. of $10 \mathrm{~K} \mathrm{~min}^{-1}$. This T-onset decreased with an increased heating rate. The lowest T-onset, $166^{\circ} \mathrm{C}$, was observed at a heating rate of $50 \mathrm{~K} \mathrm{~min}^{-1}$. In thermogravimetric analysis of un-leached biomass, the temperatures which corresponds to the maximum weight loss of hemicellulose were noticed at the heating rates of 10 and $20 \mathrm{~K} \mathrm{~min}^{-1}$ and was absence at temperatures of 30 and $50 \mathrm{~K} \mathrm{~min}^{-1}$. The trend for the T-peak was similar to the T-onset, which showed decreasing values when the heating rates increased. However, the temperature for T-offset increased with an increased heating rate.

Similarly, a decrease of the T-onset was also observed for leached biomass at increased heating rates. At the heating rates of 10 and $30 \mathrm{~K} \mathrm{~min}^{-1}$, the T-onsets for leached biomass $\left(221\right.$ and $196^{\circ} \mathrm{C}$, respectively) were slightly lower than those for un-leached biomass (228 and $197^{\circ} \mathrm{C}$, respectively). Then, the temperature corresponding to a maximum mass loss of hemicellulose was only noticed at a heating rate of $10 \mathrm{~K} \mathrm{~min}^{-1}$. For the T-peak, a decreasing trend was detected from the heating rates of $20 \mathrm{~K} \mathrm{~min}^{-1}$ with $323^{\circ} \mathrm{C}$ to $50 \mathrm{~K} \mathrm{~min}^{-1}$ with $290{ }^{\circ} \mathrm{C}$. The $\mathrm{T}$-peak at $10 \mathrm{~K} \mathrm{~min}^{-1}$ was insignificantly different from the value at $20 \mathrm{~K} \mathrm{~min}^{-1}$. Compared to the data for un-leached biomass, there was a decreasing value of the T-peak for leached biomass at heating rates of 10 and $20 \mathrm{~K} \mathrm{~min}^{-1}$. A shift from $330^{\circ} \mathrm{C}$ for un-leached biomass to $323^{\circ} \mathrm{C}$ for leached biomass was noticed at $10 \mathrm{~K} \mathrm{~min}^{-1}$ and from $326^{\circ} \mathrm{C}$ to $323^{\circ} \mathrm{C}$ at $20 \mathrm{~K} \mathrm{~min}^{-1}$. Also, there was an increase in the T-offset value, giving $363^{\circ} \mathrm{C}$ at $10 \mathrm{~K} \mathrm{~min}^{-1}$ and $447^{\circ} \mathrm{C}$ at $50 \mathrm{~K} \mathrm{~min}^{-1}$.

In contrast, the study by Jenkins, et al. [74] found that there was a delayed value for leached rice straw, compared to un-leached rice straw. The T-peak value for leached biomass occurred around $325^{\circ} \mathrm{C}$, while for un-leached biomass, it occurred at approximately $280^{\circ} \mathrm{C}$ [74]. Interestingly, Lv, et al. [80] found that the thermal behaviour of the acid-washed biomass showed a similar phenomenon to that of un-washed cellulose, corncob, and rice husk. It is expected that the thermal characteristics of biomass are strongly correlated to the biomass

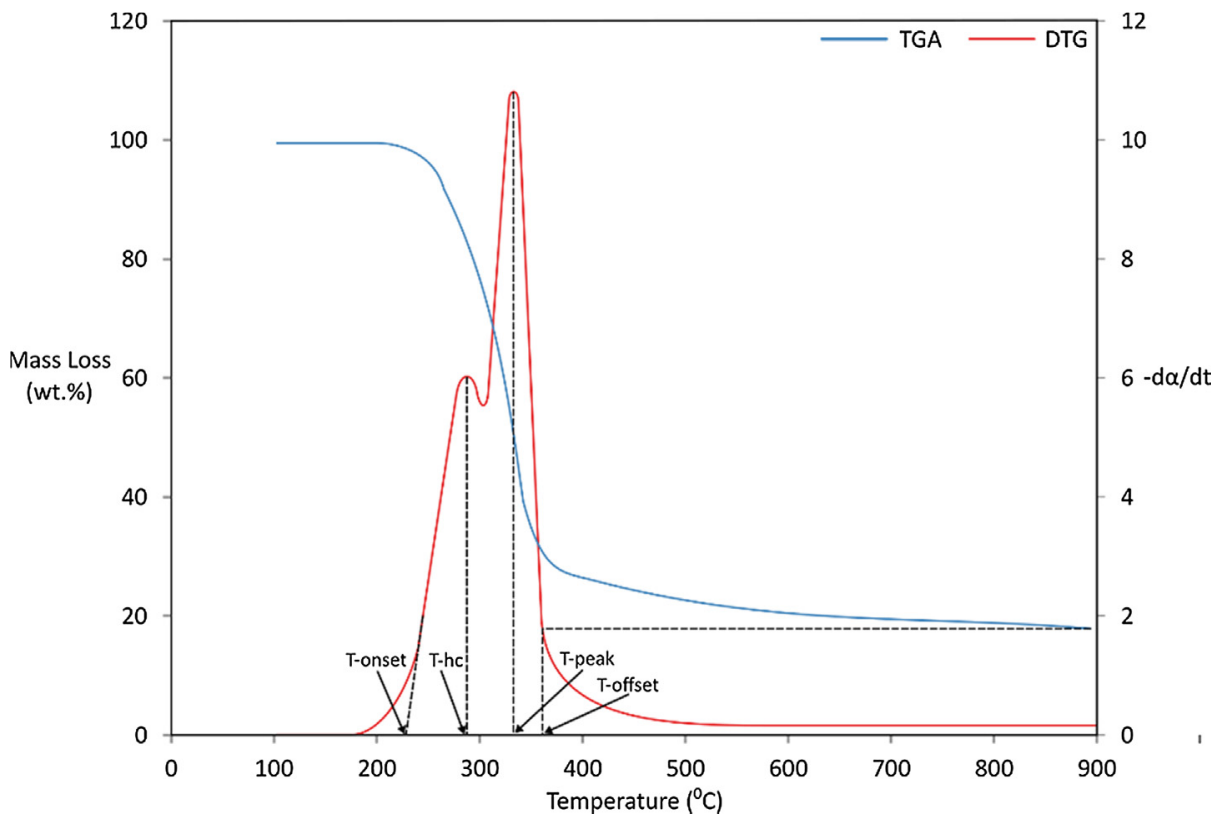

Fig. 3. Definition of the characteristics of thermogravimetric curves. 
Table 4

Thermal properties of un-leached (L1) and leached (L2) lignocellulose biomass without catalyst and with H-ZSM-5:Al-MCM-41 ratio of 3:1 (HA-31) at different heating rates.

\begin{tabular}{|c|c|c|c|c|c|c|c|c|c|}
\hline \multirow[t]{2}{*}{ Sample } & \multirow{2}{*}{$\begin{array}{l}\text { Heating } \\
\text { Rate (K/ } \\
\text { min) }\end{array}$} & \multicolumn{4}{|c|}{$\begin{array}{l}\text { Thermal properties without } \\
\text { catalyst }\end{array}$} & \multicolumn{4}{|c|}{$\begin{array}{l}\text { Thermal properties with HA-31 } \\
\text { catalyst }\end{array}$} \\
\hline & & $\begin{array}{l}\mathrm{T}- \\
\text { onset } \\
\left({ }^{\circ} \mathrm{C}\right)\end{array}$ & $\begin{array}{l}\mathrm{T}- \\
\text { hc } \\
\left({ }^{\circ} \mathrm{C}\right)\end{array}$ & $\begin{array}{l}\text { T- } \\
\text { peak } \\
\left({ }^{\circ} \mathrm{C}\right)\end{array}$ & $\begin{array}{l}\mathrm{T}- \\
\text { offset } \\
\left({ }^{\circ} \mathrm{C}\right)\end{array}$ & $\begin{array}{l}\mathrm{T}- \\
\text { onset } \\
\left({ }^{\circ} \mathrm{C}\right)\end{array}$ & $\begin{array}{l}\mathrm{T}- \\
\text { hc } \\
\left({ }^{\circ} \mathrm{C}\right)\end{array}$ & $\begin{array}{l}\text { T- } \\
\text { peak } \\
\left({ }^{\circ} \mathrm{C}\right)\end{array}$ & $\begin{array}{l}\mathrm{T}- \\
\text { offset } \\
\left({ }^{\circ} \mathrm{C}\right)\end{array}$ \\
\hline \multirow[t]{4}{*}{ L1 } & 10 & 228 & 291 & 330 & 364 & 230 & 268 & 330 & 362 \\
\hline & 20 & 208 & 280 & 326 & 384 & 204 & & 313 & 386 \\
\hline & 30 & 197 & & 307 & 416 & 184 & & 304 & 435 \\
\hline & 50 & 166 & & 287 & 438 & 167 & & 288 & 486 \\
\hline \multirow[t]{4}{*}{ L2 } & 10 & 221 & 278 & 323 & 363 & 237 & 281 & 332 & 368 \\
\hline & 20 & 209 & & 323 & 394 & 209 & & 324 & 392 \\
\hline & 30 & 196 & & 311 & 412 & 183 & & 304 & 414 \\
\hline & 50 & 166 & & 290 & 447 & 166 & & 296 & 371 \\
\hline
\end{tabular}

components, which are also different between biomass species. The finding of the present study suggests that the removal of AAEM through an acid-leaching process promoted a slightly shifting of T-hc and T-peak toward lower temperatures $\left(278-323^{\circ} \mathrm{C}\right)$, compared to the values from un-leached biomass $\left(280-330^{\circ} \mathrm{C}\right)$. However, there was significant difference of mass losses (12.4-18.2\%) between leached and un-leached biomass.

A different mass loss had evolved from different heating rates. Table 5 presents and compares the mass losses from un-leached and leached biomass at different heating rates in its respective phases. The moisture removal process was observed during the Phase 1 for both the un-leached and leached lignocellulose. The mass losses percentage for Phase 1 is in the range of $0.48-3.14 \%$, Table 5. It implies that the lignocellulose biomass, either un-leached or leached, can be used directly in thermochemical processes, such as a catalytic pyrolysis, where the moisture content of the biomass is lower than $10 \mathrm{wt} \%$ [81]. The low moisture content will increase the heating value of lignocellulose biomass and enhance the quality of bio-oil [75]. Similarly, some studies [82-84] found that the rate of pyrolysis from room temperature to around $200{ }^{\circ} \mathrm{C}$ was very slow and resulted in a less than $5 \%$ mass loss, corresponding to the moisture content release process. Since the $50-70 \%$ mass loss occurred in a temperature range of $160-450{ }^{\circ} \mathrm{C}$, the kinetic study was focused on the process during Phase 2.

During the Phase 2, the thermal degradation hastens as the heating rate is increased. Although the mass loss percentage decreased from $68.62 \mathrm{wt} \%$ at $10 \mathrm{~K} \mathrm{~min}^{-1}$ to $68.34 \mathrm{wt} \%$ at $20 \mathrm{~K} \mathrm{~min}^{-1}$, a strong increase of the mass loss percentage to $75.54 \mathrm{wt} \%$ at $50 \mathrm{~K} \mathrm{~min}^{-1}$ prevailed. The decreased value of the mass loss percentage in Phase 3 shows that the lignin decomposition was hindered by the increase of the heating rates. The highest percentage of mass loss, $12.05 \mathrm{wt} \%$, was achieved at a heating rate of $10 \mathrm{~K} \mathrm{~min}^{-1}$, while the lowest value $(5.20 \mathrm{wt} \%)$ was obtained at a heating rate of $50 \mathrm{~K} \mathrm{~min}^{-1}$. Additionally, there was a decrease in mass loss percentage for Phase 4, which represent the residual solid from the process, as the heating rate increased from $20 \mathrm{~K} \mathrm{~min}^{-1}(19.88 \mathrm{wt} \%)$ to $50 \mathrm{~K} \mathrm{~min}^{-1}(16.43 \mathrm{wt} \%)$. However, a $2.07 \mathrm{wt} \%$ increase in mass loss percentage was noticed from $10 \mathrm{~K} \mathrm{~min}^{-1}$ to $20 \mathrm{~K} \mathrm{~min}^{-1}$.

A similar trend in Phase 2 occurred for the leached biomass, as a $84.72 \%$ of weight loss was observed at a heating rate of $10 \mathrm{~K} \mathrm{~min}^{-1}$ and increased to $87.97 \%$ at a heating rate of $50 \mathrm{~K} \mathrm{~min}^{-1}$. An increase of $12.4-18.2 \%$ was noticed for the mass loss percentage for leached biomass compared to un-leached biomass. This finding implies that a pretreatment leaching process prior to a thermal conversion led to a high devolatilization. Nevertheless, the lignin decomposition, represented in Phase 3, followed a decreasing trend, giving mass loss percentage from $5.37 \mathrm{wt} \%$ at $10 \mathrm{~K} \mathrm{~min}^{-1}$ to $2.83 \mathrm{wt} \%$ at $50 \mathrm{~K} \mathrm{~min}^{-1}$. The mass loss percentages in Phase 3 for leached biomass was $2.3-6.7 \%$ lower than the percentages for un-leached biomass. It is assumed that the lignin was mostly decomposed in Phase 2 for leached biomass. Furthermore, the residual solid in Phase 4 decreased from $8.54 \mathrm{wt} \%$ at $10 \mathrm{~K} \mathrm{~min}^{-1}$ to $6.42 \mathrm{wt} \%$ at $50 \mathrm{~K} \mathrm{~min}^{-1}$.

The findings above is consistent with the result of Gomez, et al. [85]. They investigated the thermal characteristics of beech wood chips and found that the water-washed sample had a 3\% less solid residual compared to un-treated samples. The water-washed sample gave a $11 \mathrm{wt} \%$ of solid residual, while the un-leached sample obtained $14 \mathrm{wt} \%$ [85]. Varhegyi, et al. [86] also observed that the effect of waterwashing pre-treatment had smaller effects for beech wood. There was only small increases by $9 \mathrm{~K}$ for T-peak, even though there was a significant decrease of the solid residual by $7 \%$ when using hot water washing [86].

\subsection{Influence of catalyst ratio}

Considering the potential mixture H-ZSM-5:Al-MCM-41 ratio of 3:1 with respect to favourable compounds [21] as well as Benzene, Toluene, and Xylene (BTX) [51] contents in bio-oil, the influence of this catalyst mixture was studied in the pyrolysis of leached lignocellulose biomass. Other variation of H-ZSM-5:Al-MCM-41 ratios: H (1:0), HA-71 (7:1), HA-31 (3:1), HA-11 (1:1), and A (0:1) were also investigated and the complete results of them were provided in the supplement pages.

TG and DTG curves from the un-leached and leached lignocellulose pyrolysis process with H-ZSM-5:Al-MCM-41 ratio of 3:1 are shown in Fig. 4. Fig. 4(a) and (b) can be compared with Fig. 2(a) and (b), respectively. This comparison shows that all test runs showed similar trends of mass loss as a function of temperature. Fig. 4 also illustrates four stages, Phase 1, 2, 3, and 4, of the biomass decomposition. In general, the trend was close to the experiments without using a catalyst. Phase 1 represents a drying stage, Phase 2 started around $160{ }^{\circ} \mathrm{C}$, followed by Phase 3 at $360^{\circ} \mathrm{C}$ and Phase 4 up to $900{ }^{\circ} \mathrm{C}$. The difference was

Table 5

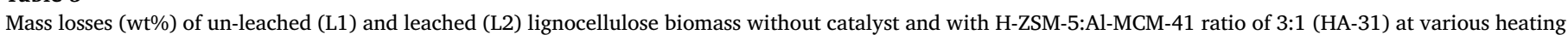
rates.

\begin{tabular}{|c|c|c|c|c|c|c|c|c|c|}
\hline \multirow[t]{2}{*}{ Sample } & \multirow[t]{2}{*}{ Heating Rate $(\mathrm{K} / \mathrm{min})$} & \multicolumn{4}{|c|}{ Mass losses (wt.\%), without catalyst } & \multicolumn{4}{|c|}{ Mass losses (wt.\%), with HA-31 catalyst } \\
\hline & & Phase 1 & Phase 2 & Phase 3 & Phase 4 & Phase 1 & Phase 2 & Phase 3 & Phase 4 \\
\hline \multirow[t]{4}{*}{ L1 } & 10 & 1.52 & 68.62 & 12.05 & 17.81 & 3.26 & 64.95 & 4.31 & 27.48 \\
\hline & 20 & 3.14 & 68.34 & 8.64 & 19.88 & 2.49 & 65.12 & 3.38 & 29.01 \\
\hline & 30 & 2.59 & 70.91 & 8.03 & 18.47 & 0.95 & 67.40 & 2.51 & 29.13 \\
\hline & 50 & 2.83 & 75.54 & 5.20 & 16.43 & 1.11 & 68.33 & 1.46 & 29.10 \\
\hline \multirow[t]{4}{*}{ L2 } & 10 & 1.36 & 84.72 & 5.37 & 8.54 & 2.05 & 65.71 & 4.51 & 27.74 \\
\hline & 20 & 1.10 & 86.29 & 4.89 & 7.72 & 3.52 & 66.24 & 4.01 & 26.22 \\
\hline & 30 & 0.48 & 89.11 & 4.00 & 6.42 & 5.38 & 66.73 & 4.11 & 23.78 \\
\hline & 50 & 1.95 & 87.97 & 2.83 & 7.25 & 2.84 & 62.44 & 5.88 & 28.84 \\
\hline
\end{tabular}

Phase 1 (room temperature - T-onset); Phase 2 (T-onset - T-offset); Phase 3 (T-offset - $900{ }^{\circ} \mathrm{C}$ ); Phase 4 (> $900{ }^{\circ} \mathrm{C}$ ). 
(a) $-10 \mathrm{~K} / \mathrm{min}-20 \mathrm{~K} / \mathrm{min}-30 \mathrm{~K} / \mathrm{min}-50 \mathrm{~K} / \mathrm{min}$

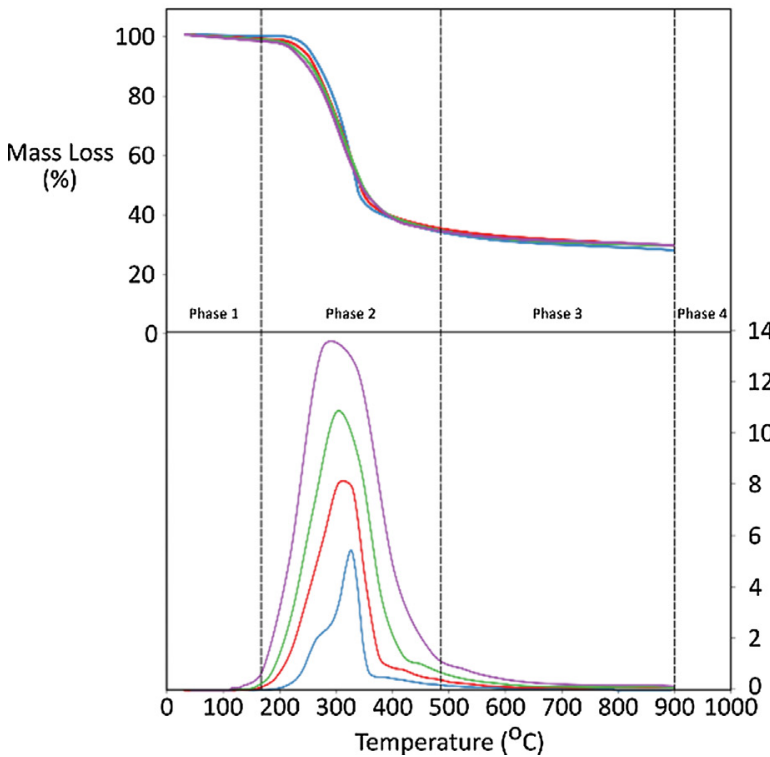

(b)
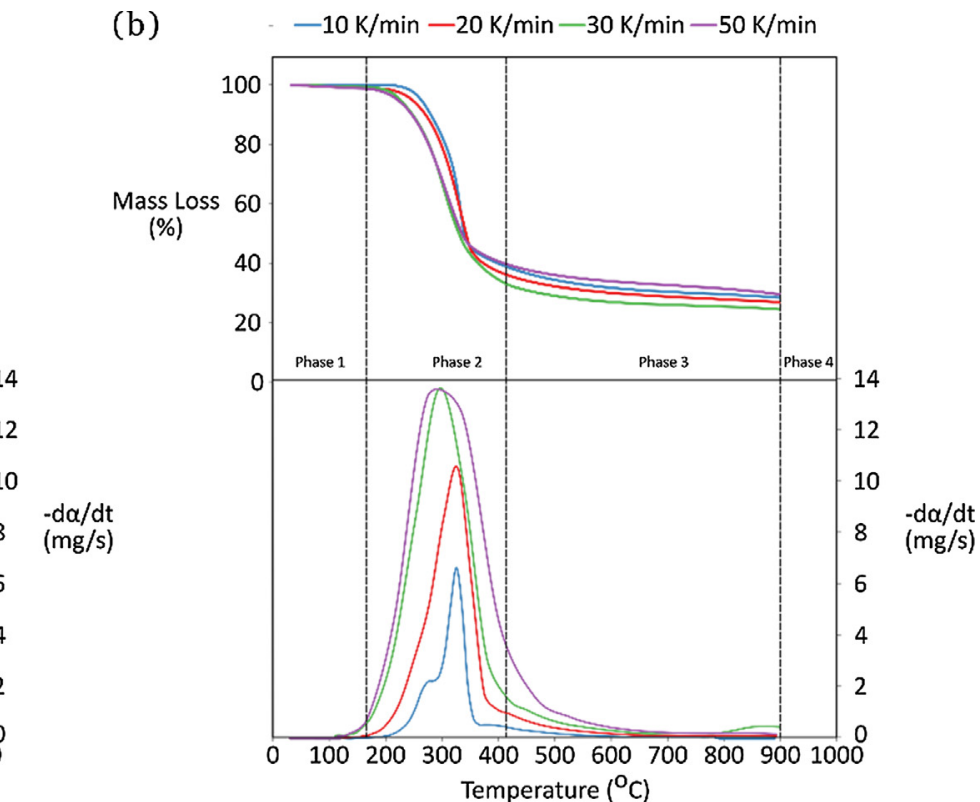

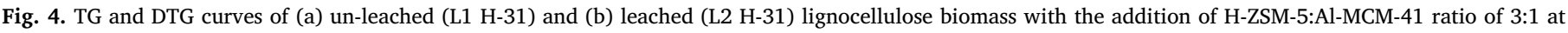
various heating rates.

found with respect to the range of temperature corresponding to Phase 2. For the experiments with catalyst, Phase 2 indicated a range of temperature from 160 to $486^{\circ} \mathrm{C}$, while the experiments without using a catalyst showed a range of $160-447^{\circ} \mathrm{C}$. The process operated using a catalyst run to a $39^{\circ} \mathrm{C}$ higher temperature compared to that without catalyst.

The thermal properties of lignocellulose biomass, un-leached and leached, with the addition of H-ZSM-5:Al-MCM-41 ratio of 3:1 for different heating rates are summarized in Table 4. The T-onset, which represents the start of the devolatilization, decreased as the heating rates increased from $221^{\circ} \mathrm{C}$ at $10 \mathrm{~K} \mathrm{~min}^{-1}$ to $166^{\circ} \mathrm{C}$ at $50 \mathrm{~K} \mathrm{~min}^{-1}$. The hemicellulose devolatilization was only noticed at $10 \mathrm{~K} \mathrm{~min}^{-1}$ with a temperature of $278^{\circ} \mathrm{C}$. The decreased values were also observed for the T-peak from $323^{\circ} \mathrm{C}$ at 10 and $20 \mathrm{~K} \mathrm{~min}^{-1}$ to $290{ }^{\circ} \mathrm{C}$ at $50 \mathrm{~K} \mathrm{~min}^{-1}$. Additionally, the T-offset showed an increase from $363^{\circ} \mathrm{C}$ at $10 \mathrm{~K} \mathrm{~min}^{-1}$ to $447^{\circ} \mathrm{C}$ at $50 \mathrm{~K} \mathrm{~min}^{-1}$.

Comparably, a decrease of T-onset value was also observed in the case of leached biomass using a H-ZSM-5:Al-MCM-41 ratio of 3:1. As the heating rates increased from 10 to $50 \mathrm{~K} \mathrm{~min}^{-1}$, the T-onset values decreased from 237 to $166^{\circ} \mathrm{C}$. There was no significant shifting in temperature between un-leached and leached biomass experiments, even though a $7{ }^{\circ} \mathrm{C}$ increase in temperature for leached biomass was observed at $10 \mathrm{~K} \mathrm{~min}^{-1}$. The temperature corresponding to hemicellulose devolatilization was only indicated at heating rate of $10 \mathrm{~K} \mathrm{~min}^{-1}$. For the T-peak value, a decrease from $332^{\circ} \mathrm{C}$ at $10 \mathrm{~K} \mathrm{~min}^{-1}$ to $296^{\circ} \mathrm{C}$ at $50 \mathrm{~K} \mathrm{~min}^{-1}$ was detected, whereas for T-offset, there was an increase from $368{ }^{\circ} \mathrm{C}$ at $10 \mathrm{~K} \mathrm{~min}^{-1}$ to $371{ }^{\circ} \mathrm{C}$ at $50 \mathrm{~K} \mathrm{~min}^{-1}$. The finding of the present study suggest that the rate of degradation is delayed for leached lignocellulose compared to the un-leached lignocellulose with 3:1 ratio of H-ZSM-5/Al-MCM-41.

The thermal properties from lignocellulose biomass with the $\mathrm{H}$ ZSM-5:Al-MCM-41 ratio of 3:1 can be compared to the thermal properties of it without catalyst, presented in Table 4, which shows the degradation peak temperatures (T-peak). For both cases of un-leached lignocellulose and leached lignocellulose, mostly shifted to higher values when using H-ZSM-5/Al-MCM-31 ratio of 3:1. Wang, et al. [87] found differences suggesting that H-ZSM- 5 catalyst led to a lowering of the values of the degradation peak temperatures for the blended mixture of corn stove and HDPE. The negation effect of catalyst mixture in the present study may be explained by the correlation between the degradation rate and coke formation rate, which will be presented later as mass losses during the thermal degradation.

Table 5 shows the mass losses from un-leached and leached biomass with H-ZSM-5:Al-MCM-41 ratio of 3:1. During the Phase 1, the moisture removal was at the level below 5.5\% for all test runs. For Phase 2, the mass loss percentages increased with increased heating rates for both un-leached and leached biomasses. From the un-leached biomass experiments, the percentage of mass loss increased from $64.95 \mathrm{wt} \%$ at $10 \mathrm{~K} \mathrm{~min}^{-1}$ to $68.33 \mathrm{wt} \%$ at $50 \mathrm{~K} \mathrm{~min}^{-1}$, while for the leached biomass, it rose from $65.71 \mathrm{wt} \%$ at $10 \mathrm{~K} \mathrm{~min}^{-1}$ to $66.73 \mathrm{wt} \%$ at $30 \mathrm{~K} \mathrm{~min}^{-1}$, before decreasing to $62.44 \mathrm{wt} \%$ at $50 \mathrm{~K} \mathrm{~min}^{-1}$.

A similar trend was observed during Phase 3 . The experiments with un-leached biomass obtained a decrease of the mass loss percentages from $4.31 \mathrm{wt} \%$ at $10 \mathrm{~K} \mathrm{~min}^{-1}$ to $1.46 \mathrm{wt} \%$ at $50 \mathrm{~K} \mathrm{~min}^{-1}$, whereas for leached biomass experiments, the percentages decreased from $4.51 \mathrm{wt}$ $\%$ at $10 \mathrm{~K} \mathrm{~min}^{-1}$ to $4.11 \mathrm{wt} \%$ at $30 \mathrm{~K} \mathrm{~min}^{-1}$ and increased to $5.88 \mathrm{wt} \%$ at $50 \mathrm{~K} \mathrm{~min}^{-1}$. The decreasing of mass loss percentage during Phase 3 is assumed to reflect the decay in the reaction intensity. Within Phase 4, coke, catalyst, and ash left from the process as the final residual.

A decrease of mass losses during Phase 2 was observed for the measurements using a catalyst mixture compared to measurements without a catalyst, Table 5. In the case of un-leached biomass, Phase 2 from the measurement with catalyst mixture gave mass losses that were 3.2-7.2 wt\% lower compared to when no catalyst mixture was used. The decrease of mass losses was more significant for leached biomass cases. Specifically, the measurement with catalyst mixture obtained $19-26$ wt $\%$ lower than without catalyst.

Furthermore, an increase of solid residual was observed in Phase 4. The mass losses of 9.1-12.7 wt $\%$ more was observed from the measurement with catalyst mixture for the un-leached biomass and 18.5-21.6 wt $\%$ more for the leached biomass, in comparison to the measurements without catalyst. These results clarify that using the catalyst mixture lowers the rate of degradation due to a coke deposition in the catalyst pores. The formation of coke was up to two times more severe in the case of leached biomass compared to un-leached biomass, even though the leaching affected positively on the devolatilization of biomass with a value of 3.5-6.4 times higher than without an acid leaching pre-treatment. 
Table 6

TGA kinetic calculations of un-leached and leached lignocellulose biomass with second-order reaction model (F2) as the selected mechanism at various heating rates.

\begin{tabular}{|c|c|c|c|c|}
\hline \multirow[t]{2}{*}{ Samples } & \multicolumn{4}{|c|}{ Heating rates $\left(\mathrm{K} \mathrm{min}^{-1}\right)$} \\
\hline & 10 & 20 & 30 & 50 \\
\hline \multicolumn{5}{|c|}{ Un-leached lignocellulose } \\
\hline & $\mathrm{Ea}\left(\mathrm{kJ} \mathrm{mol}^{-1}\right)$ & $\mathrm{Ea}\left(\mathrm{kJ} \mathrm{mol}^{-1}\right)$ & $\mathrm{Ea}\left(\mathrm{kJ} \mathrm{mol}^{-1}\right)$ & $\mathrm{Ea}\left(\mathrm{kJ} \mathrm{mol}^{-1}\right)$ \\
\hline L1 & 26.94 & 19.93 & 16.38 & 15.35 \\
\hline L1 HA-31 & 25.56 & 19.05 & 18.92 & 18.29 \\
\hline \multicolumn{5}{|c|}{ Leached lignocellulose } \\
\hline & $\mathrm{Ea}\left(\mathrm{kJ} \mathrm{mol}^{-1}\right)$ & $\mathrm{Ea}\left(\mathrm{kJ} \mathrm{mol}^{-1}\right)$ & $\mathrm{Ea}\left(\mathrm{kJ} \mathrm{mol}^{-1}\right)$ & $\mathrm{Ea}\left(\mathrm{kJ} \mathrm{mol}^{-1}\right)$ \\
\hline L2 & 24.05 & 20.40 & 11.91 & 15.91 \\
\hline L2 HA-31 & 21.80 & 19.29 & 17.62 & 16.88 \\
\hline
\end{tabular}

\subsection{Kinetics and reaction mechanisms parameters}

Several forms of mechanism functions, Supplement S1, were used to find a better approximation for the activation energy. The activation energies obtained from calculations with those mechanisms are given in the supplement pages. Jankovic and Jankovic [88] found that a threedimensional (D4) diffusion could be used to describe the thermal degradation of beech wood with Ea value of $155.5 \mathrm{~kJ} \mathrm{~mol}^{-1}$. This value is in agreement with the result for un-leached biomass at $20 \mathrm{~K} \mathrm{~min}^{-1}$ $\left(\mathrm{Ea}=156.5 \mathrm{~kJ} \mathrm{~mol}^{-1}\right)$ when using the same reaction model (D4). This value of $156.5 \mathrm{~kJ} \mathrm{~mol}^{-1}$ is also comparable with the value of Ea reported by Blasi and Branca [89] $\left(\mathrm{Ea}=157.0 \mathrm{~kJ} \mathrm{~mol}^{-1}\right)$. However, the diffusion mechanisms (D1, D2, D3, and D4) in the present study were not statistically satisfactory. The square- $R$ for these mechanisms showed less than 0.99 in most cases.

Another study by Radojevic, et al. [90] resulted in 225.04 and $227.76 \mathrm{~kJ} \mathrm{~mol}^{-1}$ as Ea values for beech sawdust, calculated by Friedman and Kissinger-Akahira-Sunose (KAS) methods, respectively. By using a first order mechanism (F1), Grønli, et al. [91] found an Ea value of $127 \mathrm{~kJ} \mathrm{~mol}^{-1}$ for beech wood. Ding, et al. [92] estimated that the activation energies of beech wood were $148.63-174.44 \mathrm{~kJ} \mathrm{~mol}^{-1}$ by using the Flynn-Wall-Ozawa method (FWO) and $146.84-172.21 \mathrm{~kJ} \mathrm{~mol}^{-1}$ by KAS. The findings of the present study also suggest that different values of activation energies were obtained from different kinetic mechanism. It can be concluded that the apparent activation energy (Ea) depends on the considered kinetic functions [88].

This study indicates that the F2 mechanism was able to illustrate the catalytic pyrolysis process, proven by that the coefficient of determination $\left(\mathrm{R}^{2}\right)$ was more than 0.99 compared to other mechanism and it applied to every heating rates. Results of the kinetic calculation of lignocellulose biomass with second-order reaction model (F2) under different heating rates, either without catalyst or with the catalyst addition, are shown in Table 6.

As observed from Table 6, as the heating rates increased, the activation energies decreased for the process without using catalysts (L1 and L2), either for un-leached or leached lignocellulose. Similar case occurred in the processes using catalysts (L1 H-31 and L2 H-31). However, for the un-leached lignocellulose, the activation energies from the catalytic process (L1 HA-31) at heating rate 30 and $50 \mathrm{~K} \mathrm{~min}^{-1}$ were $15-20 \%$ higher compared to the process without using a catalyst (L1). However, for the leached lignocellulose, the activation energies for the catalytic process (L2 HA-31) were 6-48\% higher than un-catalysed process (L2). In most of cases, leaching resulted in a reduction of the activation energies, which implied an increase in the reaction rate [74]. The results of the present study suggest that it is advantageous to use acid leaching as a treatment prior to the catalytic pyrolysis to reach high devolatilization and reaction rates.

\section{Conclusion}

The study was designed to determine the effect of acid leaching on thermal degradation of lignocellulose biomass without or with the use of H-ZSM-5/Al-MCM-41 catalyst mixtures. The acid leaching processes were carried out using different concentrations of acetic acid $(0.3,1.0$, 5.0 , and $10.0 \mathrm{wt} \%)$, temperatures $\left(30,60\right.$, and $\left.90^{\circ} \mathrm{C}\right)$, and residence times (30 and $120 \mathrm{~min}$ ). In addition, the activation energies were calculated based on solid-state reaction mechanism.

The leaching parameters to produce leached biomass for the TGA experiments were set to $30 \mathrm{~min}, 30{ }^{\circ} \mathrm{C}$ and $5 \mathrm{wt} \%$ acetic acid in the leaching liquid, with respect to economic aspects. At these parameters a significant reduction of AAEM in the leached biomass can be achieved (Ca: 59\%, Mg: 95\%, K: 99\%, and Na: 96\%).

The HHV value is not significantly influenced by the acid-leaching pre-treatment, even though it should be noted that the mineral content in leached biomass is clearly decreased. The HHV values for un-leached and leached biomass were 19.42 and $19.14 \mathrm{MJ} / \mathrm{kg}$, respectively, calculated by using the Milne formula.

The removal of AAEM significantly affected the degradation of hemicellulose, cellulose, and lignin. There were an 12.4-18.2\% increase of mass losses in Phase 2 and a lower mass loss in Phase 4 for leached biomass, compared to un-leached biomass, even though there was no significant shift in the temperature profiles between un-leached and leached biomass degradation.

Furthermore, it is advantageous to use acid leaching process as a treatment prior to catalytic pyrolysis to reach high devolatilization and reaction rate. The second order (F2) mechanism was able to illustrate the catalytic pyrolysis process, proven by that the coefficient of determination $\left(\mathrm{R}^{2}\right)$ reached a value higher than 0.99 compared to the other studied mechanism.

\section{Acknowledgements}

The financial support from the Swedish Energy AgencyEnergimydigheten under the ERA-NET Bioenergy program No. 43911-1 and from the Austrian climate and energy fund under its program "e!MISSION" are highly acknowledged.

\section{Appendix A. Supplementary data}

Supplementary data to this article can be found online at https:// doi.org/10.1016/j.fuel.2019.116086.

\section{References}

[1] Levin K. New Global CO2 Emissions Numbers Are in. They're Not Good. World Resour Inst 2018. https://www.wri.org/blog/2018/12/new-global-co2-emissionsnumbers-are-they-re-not-good (accessed June 3, 2019).

[2] Harvey C, E\&E News. CO2 Emissions Reached an All-Time High in 2018. Sci Am 2018. https://www.scientificamerican.com/article/co2-emissions-reached-an-alltime-high-in-2018/ (accessed June 3, 2019).

[3] López-González D, Fernandez-Lopez M, Valverde JL, Sanchez-Silva L. Thermogravimetric-mass spectrometric analysis on combustion of lignocellulosic biomass. Bioresour Technol 2013;143:562-74. https://doi.org/10.1016/j.biortech. 2013.06.052.

[4] Shen DK, Gu S, Luo KH, Bridgwater AV, Fang MX. Kinetic study on thermal decomposition of woods in oxidative environment. Fuel 2009;88:1024-30. https:// doi.org/10.1016/j.fuel.2008.10.034.

[5] Guerrero MRB, da Silva Marques, Paula M, Zaragoza MM, Gutiérrez JS, Velderrain VG, et al. Thermogravimetric study on the pyrolysis kinetics of apple pomace as waste biomass. Int J Hydrogen Energy 2014;39:16619-27. https://doi.org/10. 1016/j.ijhydene.2014.06.012.

[6] Environmental and Energy Study Institute. Bioenergy (Biofuels and Biomass) n.d. https://www.eesi.org/topics/bioenergy-biofuels-biomass/description (accessed May 23, 2019).

[7] IEA Bioenergy. Future Biomass-Based Transport Fuels: Summary and Conclusions from the IEA Bioenergy ExCo67 Workshop. 2012.

[8] Zhang L, Liu R, Yin R, Mei Y. Upgrading of bio-oil from biomass fast pyrolysis in China: a review. Renew Sustain Energy Rev 2013;24:66-72. https://doi.org/10. 1016/j.rser.2013.03.027. 
[9] Liu C, Wang H, Karim AM, Sun J, Wang Y. Catalytic fast pyrolysis of lignocellulosic biomass. Chem Soc Rev 2014;43:7594-623. https://doi.org/10.1039/C3CS60414D.

[10] Wu W, Mei Y, Zhang L, Liu R, Cai J. Effective activation energies of lignocellulosic biomass pyrolysis. Energy Fuels 2014;28:3916-23. https://doi.org/10.1021/ ef5005896.

[11] Wang L, Lei H, Liu J, Bu Q. Thermal decomposition behavior and kinetics for pyrolysis and catalytic pyrolysis of Douglas fir. RSC Adv 2018;8:2196-202. https:// doi.org/10.1039/C7RA12187C.

[12] Kabir G, Hameed BH. Recent progress on catalytic pyrolysis of lignocellulosic biomass to high-grade bio-oil and bio-chemicals. Renew Sustain Energy Rev 2017;70:945-67. https://doi.org/10.1016/j.rser.2016.12.001.

[13] Aho A, Tokarev A, Backman P, Kumar N, Eränen K, Hupa M, et al. Catalytic pyrolysis of pine biomass over H-beta zeolite in a dual-fluidized bed reactor: effect of space velocity on the yield and composition of pyrolysis products. Top Catal 2011;54:941-8. https://doi.org/10.1007/s11244-011-9716-8.

[14] Huber GW, Iborra S, Corma A. Synthesis of transportation fuels from biomass: chemistry, catalysts, and engineering. Chem Rev 2006;106:4044-98. https://doi. org/10.1021/cr068360d.

[15] Aho A, Salmi T, Murzin DY. Catalytic pyrolysis of lignocellulosic biomass. Role Catal. Sustain. Prod. Bio-fuels Bio-chemicals Elsevier; 2013. p. 137-59. https://doi. org/10.1016/B978-0-444-56330-9.00005-X.

[16] Pütün E, Uzun BB, Pütün AE. Rapid pyrolysis of olive residue. 2. Effect of catalytic upgrading of pyrolysis vapors in a two-stage fixed-bed reactor. Energy Fuels 2009;23:2248-58. https://doi.org/10.1021/ef800978m.

[17] Stefanidis SD, Kalogiannis KG, Iliopoulou EF, Lappas AA, Pilavachi PA. In-situ upgrading of biomass pyrolysis vapors: catalyst screening on a fixed bed reactor. Bioresour Technol 2011;102:8261-7. https://doi.org/10.1016/j.biortech.2011.06. 032.

[18] Valle B, Gayubo AG, Alonso A, Aguayo AT, Bilbao J. Hydrothermally stable HZSM-5 zeolite catalysts for the transformation of crude bio-oil into hydrocarbons. Appl Catal B Environ 2010;100:318-27. https://doi.org/10.1016/j.apcatb.2010.08.008.

[19] Valle B, Gayubo AG, Aguayo AT, Olazar M, Bilbao J. Selective production of aromatics by crude bio-oil valorization with a nickel-modified HZSM-5 zeolite catalyst. Energy Fuels 2010;24:2060-70, https://doi.org/10.1021/ef901231j.

[20] Grams J, Ruppert A. Development of heterogeneous catalysts for thermo-chemical conversion of lignocellulosic biomass. Energies 2017;10:545. https://doi.org/10. 3390/en10040545.

[21] Ratnasari DK, Yang W, Jönsson PG. Two-stage ex-situ catalytic pyrolysis of lignocellulose for the production of gasoline-range chemicals. J Anal Appl Pyrolysis 2018;134:454-64. https://doi.org/10.1016/j.jaap.2018.07.012.

[22] Melligan F, Hayes MHB, Kwapinski W, Leahy JJ. Hydro-pyrolysis of biomass and online catalytic vapor upgrading with Ni-ZSM-5 and Ni-MCM-41. Energy Fuels 2012;26:6080-90. https://doi.org/10.1021/ef301244h.

[23] Marker TL, Petri JA. Gasoline and Diesel Production from Pyrolytic Lignin Produced from Pyrolysis of Cellulosic Waste. US 7,578,927 B2, 2009.

[24] Adjaye JD, Bakhshi NN. Catalytic conversion of a biomass-derived oil to fuels and chemicals I: model compound studies and reaction pathways. Biomass Bioenergy 1995;8:131-49. https://doi.org/10.1016/0961-9534(95)00018-3.

[25] Zhang H, Xiao R, Jin B, Xiao G, Chen R. Biomass catalytic pyrolysis to produce olefins and aromatics with a physically mixed catalyst. Bioresour Technol 2013;140:256-62. https://doi.org/10.1016/j.biortech.2013.04.094.

[26] Zhang H, Zheng J, Xiao R, Jia Y, Shen D, Jin B, et al. Study on pyrolysis of pine sawdust with solid base and acid mixed catalysts by thermogravimetry-fourier transform infrared spectroscopy and pyrolysis-Gas Chromatography/Mass Spectrometry. Energy Fuels 2014;28:4294-9. https://doi.org/10.1021/ef500176w.

[27] Antal MJ. Biomass pyrolysis: a review of the literature part 1-carbohydrate pyrolysis. Adv. Sol. Energy Boston, MA: Springer New York; 1983. p. 61-111. https:// doi.org/10.1007/978-1-4684-8992-7 3.

[28] Piskorz J, Radlein DSAG, Scott DS, Czernik S. Pretreatment of wood and cellulose for production of sugars by fast pyrolysis. J Anal Appl Pyrolysis 1989;16:127-42. https://doi.org/10.1016/0165-2370(89)85012-0.

[29] Mahadevan R, Adhikari S, Shakya R, Wang K, Dayton D, Lehrich M, et al. Effect of alkali and alkaline earth metals on in-situ catalytic fast pyrolysis of lignocellulosic biomass: a microreactor study. Energy Fuels 2016;30:3045-56. https://doi.org/10. 1021/acs.energyfuels.5b02984.

[30] Hu S, Jiang L, Wang Y, Su S, Sun L, Xu B, et al. Effects of inherent alkali and alkaline earth metallic species on biomass pyrolysis at different temperatures. Bioresour Technol 2015;192:23-30. https://doi.org/10.1016/j.biortech.2015.05.042.

[31] Haddad K, Jeguirim M, Guizani C, Jellali S, Limousy L, Adouni N. Influence of Alkali and Alkaline Earth Metallic (AAEM) Species on Pyrolysis Process of Cypress Sawdust (n.d).

32] Aston JE, Thompson DN, Westover TL. Performance assessment of dilute-acid leaching to improve corn stover quality for thermochemical conversion. Fuel 2016;186:311-9. https://doi.org/10.1016/j.fuel.2016.08.056.

[33] Liaw SB. Leaching of inorganic and organic matter from biomass and biochars under various conditions: equilibrium, kinetics, and implications. Curtin University; 2015

[34] Oudenhoven SRG, Westerhof RJM, Aldenkamp N, Brilman DWF, Kersten SRA. Demineralization of wood using wood-derived acid: towards a selective pyrolysis process for fuel and chemicals production. J Anal Appl Pyrolysis 2013;103:112-8. https://doi.org/10.1016/j.jaap.2012.10.002.

[35] Wigley T, Yip ACK, Pang S. The use of demineralisation and torrefaction to improve the properties of biomass intended as a feedstock for fast pyrolysis. J Anal Appl Pyrolysis 2015;113:296-306. https://doi.org/10.1016/j.jaap.2015.02.007.

[36] Oudenhoven SRG, Westerhof RJM, Kersten SRA. Fast pyrolysis of organic acid leached wood, straw, hay and bagasse: Improved oil and sugar yields. J Anal Appl
Pyrolysis 2015;116:253-62. https://doi.org/10.1016/j.jaap.2015.09.003.

[37] Kantarelis E, Yang W, Blasiak W. Production of liquid feedstock from biomass via steam pyrolysis in a fluidized bed reactor. Energy Fuels 2013;27:4748-59. https:// doi.org/10.1021/ef400580x.

[38] Persson H, Kantarelis E, Evangelopoulos P, Yang W. Wood-derived acid leaching of biomass for enhanced production of sugars and sugar derivatives during pyrolysis: influence of acidity and treatment time. J Anal Appl Pyrolysis 2017;127:329-34. https://doi.org/10.1016/j.jaap.2017.07.018.

[39] Cordero T, Rodríguez-Maroto JM, Rodríguez-Mirasol J, Rodríguez JJ. On the kinetics of thermal decomposition of wood and wood components. Thermochim Acta 1990;164:135-44. https://doi.org/10.1016/0040-6031(90)80430-7.

[40] Coriolano ACF, Oliveira AAA, Bandeira RAF, Fernandes VJ, Araujo AS. Kinetic study of thermal and catalytic pyrolysis of Brazilian heavy crude oil over mesoporous Al-MCM-41 materials. J Therm Anal Calorim 2015;119:2151-7. https://doi. org/10.1007/s10973-015-4408-4.

[41] Yorulmaz SY, Atimtay AT. Investigation of combustion kinetics of treated and untreated waste wood samples with thermogravimetric analysis. Fuel Process Technol 2009;90:939-46. https://doi.org/10.1016/j.fuproc.2009.02.010.

[42] Balasundram V, Ibrahim N, Kasmani RM, Hamid MKA, Isha R, Hasbullah H, et al. Thermogravimetric catalytic pyrolysis and kinetic studies of coconut copra and rice husk for possible maximum production of pyrolysis oil. J Clean Prod 2017;167:218-28. https://doi.org/10.1016/j.jclepro.2017.08.173.

[43] Carrier M, Auret L, Bridgwater A, Knoetze JH. Using apparent activation energy as reactivity criterion for biomass pyrolysis. Energy Fuels 2016;30:7834-41. https:// doi.org/10.1021/acs.energyfuels.6b00794.

[44] Lv P, Chang J, Wang T, Wu C, Tsubaki N. A kinetic study on biomass fast catalytic pyrolysis. Energy Fuels 2004;18:1865-9. https://doi.org/10.1021/ef0400262.

[45] Becidan M, Várhegyi G, Hustad JE, Skreiberg $\emptyset$. Thermal decomposition of biomass wastes. a kinetic study. Ind Eng Chem Res 2007;46:2428-37. https://doi.org/10. 1021/ie061468z.

[46] Ceylan S, Topçu Y. Pyrolysis kinetics of hazelnut husk using thermogravimetric analysis. Bioresour Technol 2014;156:182-8. https://doi.org/10.1016/j.biortech. 2014.01.040.

[47] Leroy V, Cancellieri D, Leoni E, Rossi J-L. Kinetic study of forest fuels by TGA model-free kinetic approach for the prediction of phenomena. Thermochim Acta 2010;497:1-6. https://doi.org/10.1016/j.tca.2009.08.001.

[48] Coriolano ACF, Silva CGC, Costa MJF, Pergher SBC, Caldeira VPS, Araujo AS. Development of HZSM-5/AlMCM-41 hybrid micro-mesoporous material and application for pyrolysis of vacuum gasoil. MicrCoriolano, ACF, Silva, CGC, Costa, MJF, Pergher, SBC, Caldeira, VPS, Araujo, AS (2013) Dev HZSM-5/AlMCM-41 Hybrid Micro-Mesoporous Mater Appl Pyrolysis Vac Gasoil Microporous Mesop 2013;172:206-12. doi:10.1016/j.micromeso.2013.01.022.

[49] Zakrzewski R. Pyrolysis kinetics of wood comparison of iso- and polythermal thermogravimetric methods. Electron J Polish Agric Univ; 2003.

[50] Boukaous N, Abdelouahed L, Chikhi M, Meniai A-H, Mohabeer C, Bechara T. Combustion of Flax Shives, beech wood, pure woody pseudo-components and their chars: a thermal and kinetic study. Energies 2018;11:2146. https://doi.org/10. 3390/en11082146.

[51] Ratnasari DK, Yang W, Jonsson P. A kinetic study of H-ZSM-5/Al-MCM-41 catalyst mixture and application for lignocellulose biomass pyrolysis. Energy Fuels 2019. https://doi.org/10.1021/acs.energyfuels.9b00866.

[52] ISO 14780:2017 (E). Solid Biofuels - Sample Preparation. (n.d).

[53] ISO 18134-2:2017. Solid Biofuels - Determination of Moisture Content - Oven Dry Method. (n.d).

[54] ISO 16948:2015 (E). Solid Biofuels - Determination of Total Content of Carbon, Hydrogen, and Nitrogen. (n.d)

[55] ISO 18122:2015. Solid Biofuels - Determination of Ash Content. (n.d)

[56] Ebrahimi-Kahrizsangi R, Abbasi MH. Evaluation of reliability of Coats-Redfern method for kinetic analysis of non-isothermal TGA. Trans Nonferrous Met Soc China 2008;18:217-21. https://doi.org/10.1016/S1003-6326(08)60039-4.

[57] Vyazovkin S. Model-free kinetics. J Therm Anal Calorim 2006;83:45-51. https:// doi.org/10.1007/s10973-005-7044-6.

[58] Khawam A, Flanagan DR. Solid-state kinetic models: basics and mathematica fundamentals. J Phys Chem B 2006;110:17315-28. https://doi.org/10.1021/ jp062746a.

[59] Khawam A, Flanagan DR. Basics and applications of solid-state kinetics: a pharmaceutical perspective. J Pharm Sci 2006;95:472-98. https://doi.org/10.1002/jps 20559.

[60] Wang N, Tahmasebi A, Yu J, Xu J, Huang F, Mamaeva A. A comparative study of microwave-induced pyrolysis of lignocellulosic and algal biomass. Bioresour Technol 2015;190:89-96. https://doi.org/10.1016/j.biortech.2015.04.038.

[61] Cai J, Liu R. Kinetic analysis of solid-state reactions: a general empirical kinetic model. Ind Eng Chem Res 2009;48:3249-53. https://doi.org/10.1021/ie8018615.

[62] Burnham AK. Introduction to chemical kinetics. Glob. Chem. Kinet. Foss. Fuels Cham: Springer International Publishing; 2017. p. 25-74. https://doi.org/10.1007/ 978-3-319-49634-4 2

[63] Oudenhoven SRG, van der Ham AGJ, van den Berg H, Westerhof RJM, Kersten SRA. Using pyrolytic acid leaching as a pretreatment step in a biomass fast pyrolysis plant: process design and economic evaluation. Biomass Bioenergy 2016;95:388-404. https://doi.org/10.1016/j.biombioe.2016.07.003.

[64] Davidsson KO, Korsgren JG, Pettersson JBC, Jäglid U. The effects of fuel washing techniques on alkali release from biomass. Fuel 2002;81:137-42. https://doi.org/ 10.1016/S0016-2361(01)00132-6.

[65] Wu H, Yip K, Kong Z, Li C-Z, Liu D, Yu Y, et al. Removal and recycling of inherent inorganic nutrient species in mallee biomass and derived biochars by water leaching. Ind Eng Chem Res 2011;50:12143-51. https://doi.org/10.1021/ 
ie200679n.

[66] Liu X, Bi XT. Removal of inorganic constituents from pine barks and switchgrass. Fuel Process Technol 2011;92:1273-9. https://doi.org/10.1016/j.fuproc.2011.01. 016.

[67] Wigley T. Improving the quality of bio-oil by fast pyrolysis of acid leached and torrefied pinus radiata. University of Canterbury; 2015.

[68] Phyllis 2 Help. ECN 2019. https://phyllis.nl/Home/Help (accessed March 14, 2019).

[69] Jahirul M, Rasul M, Chowdhury A, Ashwath N. Biofuels production through biomass pyrolysis - a technological review. Energies 2012;5:4952-5001. https://doi. org/10.3390/en5124952.

[70] Acar S, Ayanoglu A. Determination of higher heating values (HHVs) of biomass fuels. vol. 28. 2012.

[71] American Society for Testing and Materials D2015. Standard Test Method for Gross Calorific Value of Solid Fuel by the Adiabatic Bomb Calorimeter. (n.d).

[72] Jenkins BM, Bakker RR, Wei JB. On the properties of washed straw. Biomass Bioenergy 1996;10:177-200. https://doi.org/10.1016/0961-9534(95)00058-5.

[73] Sheng C, Azevedo JLT. Estimating the higher heating value of biomass fuels from basic analysis data. Biomass Bioenergy 2005;28:499-507. https://doi.org/10.1016/ j.biombioe.2004.11.008.

[74] Jenkins BM, Bakker RR, Baxter LL, Gilmer JH, Wei JB. Combustion characteristics of leached biomass. Dev. Thermochem. Biomass Convers. Dordrecht: Springer Netherlands; 1997. p. 1316-30. https://doi.org/10.1007/978-94-009-1559-6_104.

[75] El-Sayed SA, Khairy M. Effect of heating rate on the chemical kinetics of different biomass pyrolysis materials. Biofuels 2015;6:157-70. https://doi.org/10.1080/ 17597269.2015.1065590.

[76] Raveendran K. Pyrolysis characteristics of biomass and biomass components. Fuel 1996;75:987-98. https://doi.org/10.1016/0016-2361(96)00030-0.

[77] yang Q, Wu S, Lou R, Lv G. Analysis of wheat straw lignin by thermogravimetry and pyrolysis-gas chromatography/mass spectrometry. J Anal Appl Pyrolysis 2010;87:65-9. https://doi.org/10.1016/j.jaap.2009.10.006.

[78] Determination of Reaction Kinetics of Straw and Stalk of Rapeseed Using Thermogravimetric Analysis. Energy Sources 2001;23:767-74. doi:10.1080/ 009083101316862525.

[79] Kumar A, Wang L, Dzenis YA, Jones DD, Hanna MA. Thermogravimetric characterization of corn stover as gasification and pyrolysis feedstock. Biomass Bioenergy 2008;32:460-7. https://doi.org/10.1016/j.biombioe.2007.11.004.

[80] Lv D, Xu M, Liu X, Zhan Z, Li Z, Yao H. Effect of cellulose, lignin, alkali and alkaline earth metallic species on biomass pyrolysis and gasification. Fuel Process Technol
2010;91:903-9. https://doi.org/10.1016/j.fuproc.2009.09.014.

[81] Jauhiainen J, Conesa JA, Font R. Martín-Gullón I. Kinetics of the pyrolysis and combustion of olive oil solid waste. J Anal Appl Pyrolysis 2004;72:9-15. https:// doi.org/10.1016/j.jaap.2004.01.003.

[82] Wang C, Dou B, Song Y, Chen H, Yang M, Xu Y. Kinetic study on non-isothermal pyrolysis of sucrose biomass. Energy Fuels 2014;28:3793-801. https://doi.org/10. 1021/ef500940q.

[83] Yang H, Kudo S, Hazeyama S, Norinaga K, Mašek O, Hayashi J. Detailed analysis of residual volatiles in chars from the pyrolysis of biomass and lignite. Energy Fuels 2013;27:3209-23. https://doi.org/10.1021/ef4001192.

[84] Al Arni S, Bosio B, Arato E. Syngas from sugarcane pyrolysis: an experimental study for fuel cell applications. Renew Energy 2010;35:29-35. https://doi.org/10.1016/j renene.2009.07.005.

[85] Gómez CJ, Mészáros E, Jakab E, Velo E, Puigjaner L. Thermogravimetry/mass spectrometry study of woody residues and an herbaceous biomass crop using PCA techniques. J Anal Appl Pyrolysis 2007;80:416-26. https://doi.org/10.1016/j.jaap. 2007.05.003.

[86] Várhegyi G, Grønli MG, Di Blasi C. Effects of sample origin, extraction, and hotwater washing on the devolatilization kinetics of chestnut wood. Ind Eng Chem Res 2004;43:2356-67. https://doi.org/10.1021/ie034168f.

[87] Wang S, Lin X, Li Z, Yi W, Bai X. Thermal and kinetic behaviors of corn stover and polyethylene in catalytic co-pyrolysis. BioResources 2018;13:4102-17. https://doi. org /10.15376/biores.13.2.4102-4117.

[88] Janković BŽ, Janković MM. Pyrolysis of pine and beech wood under isothermal conditions: the conventional kinetic approach. Res Chem Intermed 2015;41:2201-19. https://doi.org/10.1007/s11164-013-1339-1.

[89] Di Blasi C, Branca C. Kinetics of primary product formation from wood pyrolysis. Ind Eng Chem Res 2001;40:5547-56. https://doi.org/10.1021/ie000997e.

[90] Radojević M, Janković B, Jovanović V, Stojiljković D, Manić N. Comparative pyrolysis kinetics of various biomasses based on model-free and DAEM approaches improved with numerical optimization procedure. PLoS One 2018;13:e0206657https://doi.org/10.1371/journal.pone.0206657.

[91] Grønli MG, Várhegyi G, Di Blasi C. Thermogravimetric analysis and devolatilization kinetics of wood. Ind Eng Chem Res 2002;41:4201-8. https://doi.org/10.1021/ ie0201157.

[92] Ding Y, Ezekoye OA, Lu S, Wang C. Thermal degradation of beech wood with thermogravimetry/Fourier transform infrared analysis. Energy Convers Manage 2016;120:370-7. https://doi.org/10.1016/j.enconman.2016.05.007. 


\title{
Corrigendum to "The thermal degradation of lignocellulose biomass with an acid leaching pre-treatment using a H-ZSM-5/Al-MCM-41 catalyst mixture" [Fuel 257 (2019) 116086]
}

\author{
Devy K. Ratnasari ${ }^{\mathrm{a}, *}$, Antonia Horn ${ }^{\mathrm{b}}$, Thomas Brunner ${ }^{\mathrm{b}}$, Weihong Yang ${ }^{\mathrm{a}}$, Pär G. Jönsson ${ }^{\mathrm{a}}$
}

${ }^{a}$ KTH-Royal Institute of Technology, Brinellvägen 23, 10044 Stockholm, Sweden

${ }^{\mathrm{b}}$ BIOS BIOENERGIESYSTEME GmbH, Inffeldgasse 21b, A-8010 Graz, Austria

The authors regret that an error appears in page no. 4 in the 'Results and Discussion' section [sub section 3.1. Leaching of Alkali and Alkaline Earth Metallic (AAEM) Species].

The first line:

Kesalahan! Sumber referensi tidak ditemukan. show the results of the leaching tests at different acetic acid concentrations at a liquid to solid (1/s)-ratio of $10: 1$, a temperature of $90^{\circ} \mathrm{C}$, and a residence time of
120 min.

Should be read as:

'Table 2 shows the results of the leaching test at different acetic acid concentrations at a liquid to solid (1/s)-ratio of 10:1, a temperature of $90{ }^{\circ} \mathrm{C}$, and a residence time of $120 \mathrm{~min}$.

The authors would like to apologise for any inconvenience caused.

DOI of original article: https://doi.org/10.1016/j.fuel.2019.116086

* Corresponding author.

E-mail address: dkra@kth.se (D.K. Ratnasari). 
Mathematical models for the solid-state reaction mechanism

\begin{tabular}{|c|c|c|c|}
\hline $\begin{array}{l}\text { Function } \\
\text { name }\end{array}$ & Reaction model & $g(\alpha)$ & Ref. \\
\hline \multicolumn{4}{|c|}{ Nucleation models } \\
\hline Po.7 & Power law & $\alpha^{3 / 2}$ & {$[58]$} \\
\hline $\mathrm{P} 2$ & Power law & $\alpha^{1 / 2}$ & {$[58-60]$} \\
\hline $\mathrm{P}_{3}$ & Power law & $\alpha^{1 / 3}$ & {$[58-60]$} \\
\hline $\mathrm{P}_{4}$ & Power law & $\alpha^{1 / 4}$ & {$[58-60]$} \\
\hline A1.5 & Avrami-Erofeev & {$[-\ln (1-\alpha)]^{2 / 3}$} & {$[61,62]$} \\
\hline A2 & Avrami-Erofeev & {$[-\ln (1-\alpha)]^{1 / 2}$} & {$[58-60]$} \\
\hline A3 & Avrami-Erofeev & {$[-\ln (1-\alpha)]^{1 / 3}$} & {$[58-60]$} \\
\hline A4 & Avrami-Erofeev & {$[-\ln (1-\alpha)]^{1 / 4}$} & {$[58-60]$} \\
\hline \multicolumn{4}{|c|}{ Geometrical contraction models } \\
\hline $\mathrm{R} 2$ & $\begin{array}{l}\text { Contracting cylinder } \\
\text { (contracting surface) }\end{array}$ & $1-(1-\alpha)^{1 / 2}$ & {$[58-61]$} \\
\hline $\mathrm{R}_{3}$ & $\begin{array}{l}\text { Contracting sphere (contracting } \\
\text { volume, three dimension) }\end{array}$ & $1-(1-\alpha)^{1 / 3}$ & {$[42,58-61]$} \\
\hline \multicolumn{4}{|c|}{ Diffusion models } \\
\hline D1 & $\begin{array}{l}\text { One-way transport } \\
\text { (1-D diffusion, parabola law) }\end{array}$ & $\alpha^{2}$ & {$[42,58-61]$} \\
\hline D2 & $\begin{array}{l}\text { Two-way transport } \\
\text { (2-D diffusion, valensi equation) }\end{array}$ & $\alpha+((1-\alpha) \ln (1-\alpha))$ & {$[59,63]$} \\
\hline D3 & $\begin{array}{l}\text { Three-way transport } \\
\text { (3-D diffusion, Jander equation) }\end{array}$ & $\left(1-(1-\alpha)^{1 / 3}\right)^{2}$ & {$[42,58-61]$} \\
\hline D4 & Ginstling-Brounshtein equation & $1-\frac{2}{3} \alpha-(1-\alpha)^{2 / 3}$ & {$[42,59,60,62]$} \\
\hline \multicolumn{4}{|c|}{ Reaction-order models } \\
\hline Fo/R1 & Zero-order & $\alpha$ & {$[59,60]$} \\
\hline $\mathrm{F} 1$ & $\begin{array}{l}\text { Mampel } \\
\text { (first order, Chemical reaction } n=1 \text { ) }\end{array}$ & $-\ln (1-\alpha)$ & {$[58,60,62]$} \\
\hline $\mathrm{F} 2$ & Second-order & $\frac{1}{(1-\alpha)}-1$ & {$[59,60,62]$} \\
\hline$F_{3}$ & Third order & $\frac{1}{2}\left[(1-\alpha)^{-2}-1\right]$ & {$[59,60,62]$} \\
\hline
\end{tabular}


S2

Thermal properties of un-leached lignocellulose biomass

\begin{tabular}{|c|c|c|c|c|c|}
\hline Sample & $\begin{array}{l}\text { Heating Rate } \\
\qquad\left(\mathrm{K} \mathrm{min}^{-1}\right)\end{array}$ & T-onset $\left({ }^{\circ} \mathrm{C}\right)$ & T-hc ( $\left.{ }^{\circ} \mathrm{C}\right)$ & T-peak $\left({ }^{\circ} \mathrm{C}\right)$ & T-offset $\left({ }^{\circ} \mathrm{C}\right)$ \\
\hline \multirow[t]{4}{*}{$\mathrm{L} 1$} & 10 & 228 & 291 & 330 & 364 \\
\hline & 20 & 208 & 280 & 326 & 384 \\
\hline & 30 & 197 & & 307 & 416 \\
\hline & 50 & 166 & & 287 & 438 \\
\hline \multirow[t]{4}{*}{ L1 H } & 10 & 228 & 277 & 330 & 364 \\
\hline & 20 & 212 & & 332 & 384 \\
\hline & 30 & 186 & & 304 & 439 \\
\hline & 50 & 165 & & 296 & 406 \\
\hline \multirow[t]{4}{*}{ L1 H-71 } & 10 & 228 & 272 & 329 & 361 \\
\hline & 20 & 213 & & 328 & 378 \\
\hline & 30 & 191 & & 304 & 437 \\
\hline & 50 & 163 & & 289 & 485 \\
\hline \multirow[t]{4}{*}{ L1 H-31 } & 10 & 230 & 268 & 330 & 362 \\
\hline & 20 & 204 & & 313 & 386 \\
\hline & 30 & 184 & & 304 & 435 \\
\hline & 50 & 167 & & 288 & 486 \\
\hline \multirow[t]{4}{*}{ L1 H-11 } & 10 & 227 & 270 & 362 & 369 \\
\hline & 20 & 201 & & 311 & 380 \\
\hline & 30 & 181 & & 301 & 438 \\
\hline & 50 & 154 & & 281 & 484 \\
\hline \multirow[t]{4}{*}{ L1 H-13 } & 10 & 212 & 260 & 320 & 369 \\
\hline & 20 & 193 & & 313 & 376 \\
\hline & 30 & 170 & & 303 & 437 \\
\hline & 50 & 152 & & 284 & 481 \\
\hline \multirow[t]{4}{*}{ L1 A } & 10 & 222 & 273 & 330 & 361 \\
\hline & 20 & 196 & & 310 & 378 \\
\hline & 30 & 172 & & 300 & 427 \\
\hline & 50 & 155 & & 284 & 468 \\
\hline
\end{tabular}


S3

Mass losses (wt.\%) of un-leached lignocellulose biomass

\begin{tabular}{|c|c|c|c|c|c|}
\hline Sample & $\begin{array}{l}\text { Heating Rate } \\
\qquad\left(\mathrm{K} \mathrm{min}^{-1}\right)\end{array}$ & Phase 1 & Phase 2 & Phase 3 & Phase 4 \\
\hline \multirow[t]{4}{*}{ L1 } & 10 & 1.52 & 68.62 & 12.05 & 17.81 \\
\hline & 20 & 3.14 & 68.34 & 8.64 & 19.88 \\
\hline & 30 & 2.59 & 70.91 & 8.03 & 18.47 \\
\hline & 50 & 2.83 & 75.54 & 5.20 & 16.43 \\
\hline \multirow[t]{4}{*}{ L1 H } & 10 & 2.11 & 59.85 & 9.43 & 28.60 \\
\hline & 20 & 2.19 & 66.24 & $3 \cdot 41$ & 28.17 \\
\hline & 30 & 0.77 & $67 \cdot 30$ & 2.46 & 29.46 \\
\hline & 50 & 1.09 & 62.08 & 5.63 & 31.20 \\
\hline \multirow[t]{4}{*}{ L1 H-71 } & 10 & 2.00 & 63.73 & 4.51 & 29.76 \\
\hline & 20 & 2.35 & 64.26 & 4.08 & 29.31 \\
\hline & 30 & 0.77 & 67.02 & 2.52 & 29.69 \\
\hline & 50 & 1.19 & 68.52 & 1.45 & 28.84 \\
\hline \multirow[t]{4}{*}{ L1 H-31 } & 10 & 3.26 & 64.95 & $4 \cdot 31$ & 27.48 \\
\hline & 20 & 2.49 & 65.12 & 3.38 & 29.01 \\
\hline & 30 & 0.95 & 67.40 & 2.51 & 29.13 \\
\hline & 50 & 1.11 & 68.33 & 1.46 & 29.10 \\
\hline \multirow[t]{4}{*}{ L1 H-11 } & 10 & 0.31 & 65.20 & $4 \cdot 31$ & 30.18 \\
\hline & 20 & 2.22 & 64.15 & 3.87 & 29.76 \\
\hline & 30 & 0.29 & 68.26 & 2.61 & 28.84 \\
\hline & 50 & 2.71 & 67.07 & 1.42 & 28.80 \\
\hline \multirow[t]{4}{*}{ L1 H-13 } & 10 & 1.48 & 65.92 & 4.12 & 28.48 \\
\hline & 20 & 1.68 & 60.98 & $3 \cdot 52$ & 33.81 \\
\hline & 30 & 3.76 & 66.72 & 2.50 & 27.03 \\
\hline & 50 & 0.90 & 68.02 & 1.48 & 29.59 \\
\hline \multirow[t]{4}{*}{ L1 A } & 10 & 0.52 & 68.31 & 4.78 & 26.39 \\
\hline & 20 & 1.98 & 65.59 & 4.26 & 28.17 \\
\hline & 30 & 0.76 & 72.66 & 2.70 & 23.88 \\
\hline & 50 & 0.30 & 74.69 & 2.72 & 22.29 \\
\hline
\end{tabular}


S4

Thermal properties of leached lignocellulose biomass

\begin{tabular}{|c|c|c|c|c|c|}
\hline Sample & $\begin{array}{l}\text { Heating Rate } \\
\qquad\left(\mathrm{K} \mathrm{min}^{-1}\right)\end{array}$ & T-onset $\left({ }^{\circ} \mathrm{C}\right)$ & T-hc ( $\left.{ }^{\circ} \mathrm{C}\right)$ & T-peak $\left({ }^{\circ} \mathrm{C}\right)$ & T-offset $\left({ }^{\circ} \mathrm{C}\right)$ \\
\hline \multirow[t]{4}{*}{ L2 } & 10 & 221 & 278 & 323 & 363 \\
\hline & 20 & 209 & & 323 & 394 \\
\hline & 30 & 196 & & 311 & 412 \\
\hline & 50 & 166 & & 290 & 447 \\
\hline \multirow[t]{4}{*}{ L2 H } & 10 & 242 & 284 & 333 & 367 \\
\hline & 20 & 201 & & 305 & 392 \\
\hline & 30 & 196 & & 312 & 440 \\
\hline & 50 & 165 & & 289 & 450 \\
\hline \multirow[t]{4}{*}{ L2 H-71 } & 10 & 232 & 281 & 332 & 368 \\
\hline & 20 & 197 & & 306 & 394 \\
\hline & 30 & 198 & & 308 & 408 \\
\hline & 50 & 170 & & 300 & 475 \\
\hline \multirow[t]{4}{*}{ L2 H-31 } & 10 & 237 & 281 & 332 & 368 \\
\hline & 20 & 209 & & 324 & 392 \\
\hline & 30 & 183 & & 304 & 414 \\
\hline & 50 & 166 & & 296 & 371 \\
\hline \multirow[t]{4}{*}{ L2 H-11 } & 10 & 228 & 282 & 330 & 371 \\
\hline & 20 & 187 & & 304 & 395 \\
\hline & 30 & 184 & & 309 & 429 \\
\hline & 50 & 168 & & 294 & 469 \\
\hline \multirow[t]{4}{*}{ L2 H-13 } & 10 & 229 & 283 & 330 & 370 \\
\hline & 20 & 190 & & 321 & 400 \\
\hline & 30 & 169 & & 306 & 453 \\
\hline & 50 & 162 & & 294 & 468 \\
\hline \multirow[t]{4}{*}{ L2 A } & 10 & 221 & 281 & 331 & 373 \\
\hline & 20 & 177 & & 304 & 415 \\
\hline & 30 & 206 & & 344 & 449 \\
\hline & 50 & 148 & & 285 & 458 \\
\hline
\end{tabular}


S5

Mass losses (wt.\%) of leached lignocellulose biomass

\begin{tabular}{|c|c|c|c|c|c|}
\hline Sample & $\begin{array}{l}\text { Heating Rate } \\
\qquad\left(\mathrm{K} \mathrm{min}^{-1}\right)\end{array}$ & Phase 1 & Phase 2 & Phase 3 & Phase 4 \\
\hline \multirow[t]{4}{*}{ L2 } & 10 & 1.36 & 84.72 & $5 \cdot 37$ & 8.54 \\
\hline & 20 & 1.10 & 86.29 & 4.89 & $7 \cdot 72$ \\
\hline & 30 & 0.48 & 89.11 & 4.00 & 6.42 \\
\hline & 50 & 1.95 & 87.97 & 2.83 & 7.25 \\
\hline \multirow[t]{4}{*}{ L2 H } & 10 & 2.45 & 65.69 & 4.29 & $27 \cdot 57$ \\
\hline & 20 & 3.70 & 68.04 & 3.67 & 24.58 \\
\hline & 30 & 4.43 & 66.26 & 2.60 & 26.72 \\
\hline & 50 & 0.92 & 67.71 & 2.43 & 28.94 \\
\hline \multirow[t]{4}{*}{ L2 H-71 } & 10 & 2.03 & 64.46 & 4.01 & 29.51 \\
\hline & 20 & 3.48 & 65.02 & 3.42 & 28.08 \\
\hline & 30 & 0.56 & 67.57 & 3.45 & 28.42 \\
\hline & 50 & 1.35 & 67.97 & 1.45 & 29.22 \\
\hline \multirow[t]{4}{*}{ L2 H-31 } & 10 & 2.05 & $65 \cdot 71$ & $4 \cdot 51$ & 27.74 \\
\hline & 20 & $3 \cdot 5^{2}$ & 66.24 & 4.01 & 26.22 \\
\hline & 30 & $5 \cdot 38$ & 66.73 & 4.11 & 23.78 \\
\hline & 50 & 2.84 & 62.44 & 5.88 & 28.84 \\
\hline \multirow[t]{4}{*}{ L2 H-11 } & 10 & 1.78 & 62.07 & 4.12 & 32.03 \\
\hline & 20 & 4.49 & 64.35 & $3 \cdot 50$ & 27.66 \\
\hline & 30 & 4.33 & 66.71 & 2.70 & 26.26 \\
\hline & 50 & 0.46 & 67.61 & 2.59 & 29.34 \\
\hline \multirow[t]{4}{*}{ L2 H-13 } & 10 & 0.92 & 63.46 & 4.57 & 31.05 \\
\hline & 20 & 6.11 & 63.56 & 4.93 & $25 \cdot 40$ \\
\hline & 30 & 13.99 & 61.49 & 4.95 & 19.57 \\
\hline & 50 & 2.44 & 67.32 & 2.67 & 27.56 \\
\hline \multirow[t]{4}{*}{ L2 A } & 10 & 0.52 & 60.58 & 3.95 & 34.95 \\
\hline & 20 & 0.01 & 61.79 & 2.77 & $35 \cdot 43$ \\
\hline & 30 & 1.78 & $63.5^{2}$ & 3.18 & 31.52 \\
\hline & 50 & 2.97 & 67.95 & 2.66 & 26.42 \\
\hline
\end{tabular}


Un-leached biomass

\begin{tabular}{|c|c|c|c|c|c|c|c|c|}
\hline \multirow{3}{*}{ Reaction Model } & \multicolumn{8}{|c|}{ Heating Rates $\left(\mathrm{K} \mathrm{min}^{-1}\right)$} \\
\hline & \multicolumn{2}{|c|}{10} & \multicolumn{2}{|c|}{20} & \multicolumn{2}{|c|}{30} & \multicolumn{2}{|c|}{50} \\
\hline & $\mathrm{Ea} \mathrm{kJ} \mathrm{mol}^{-1}$ & $\mathrm{R}^{2}$ & $\mathrm{Ea} \mathrm{kJ} \mathrm{mol}^{-1}$ & $\mathrm{R}^{2}$ & $\mathrm{Ea} \mathrm{kJ} \mathrm{mol}^{-1}$ & $\mathrm{R}^{2}$ & $\mathrm{Ea} \mathrm{kJ} \mathrm{mol}^{-1}$ & $\mathrm{R}^{2}$ \\
\hline \multicolumn{9}{|l|}{ Nucleation models } \\
\hline Po.7 & $8.31 \mathrm{E}-\mathrm{O} 4$ & 0.9578 & $4.99 \mathrm{E}-\mathrm{O} 4$ & 0.9314 & $4.16 \mathrm{E}-\mathrm{O} 4$ & 0.9934 & $3 \cdot 33 \mathrm{E}-04$ & 0.9684 \\
\hline $\mathrm{P} 2$ & $3 \cdot 33 \mathrm{E}-\mathrm{O} 4$ & 0.9578 & $1.66 \mathrm{E}-\mathrm{O} 4$ & 0.9314 & $1.66 \mathrm{E}-\mathrm{O} 4$ & 0.9934 & $8.31 \mathrm{E}-\mathrm{O} 5$ & 0.9684 \\
\hline $\mathrm{P}_{3}$ & $2.49 \mathrm{E}-04$ & 0.9578 & $8.31 \mathrm{E}-05$ & 0.9314 & $8.31 \mathrm{E}-\mathrm{O} 5$ & 0.9934 & $6.65 \mathrm{E}-\mathrm{O} 5$ & 0.9684 \\
\hline $\mathrm{P}_{4}$ & $1.66 \mathrm{E}-04$ & 0.9578 & $8.31 \mathrm{E}-\mathrm{O} 5$ & 0.9314 & $6.65 \mathrm{E}-\mathrm{O} 5$ & 0.9934 & $4.99 \mathrm{E}-\mathrm{O} 5$ & 0.9684 \\
\hline A1.5 & 86.96 & 0.9898 & 51.82 & 0.9918 & 33.73 & 0.9502 & 27.52 & 0.9971 \\
\hline A2 & 63.12 & 0.9890 & 36.60 & 0.9904 & 23.07 & 0.9425 & 18.35 & 0.9958 \\
\hline A3 & 39.27 & 0.9871 & 21.38 & 0.9864 & 12.42 & 0.9193 & 9.18 & 0.9907 \\
\hline A4 & 27.35 & 0.9847 & 13.77 & 0.9801 & 7.09 & 0.8758 & 4.60 & 0.9746 \\
\hline \multicolumn{9}{|l|}{ Geometrical contraction models } \\
\hline $\mathrm{R} 2$ & 129.31 & 0.9855 & 74.61 & 0.9803 & 50.44 & 0.9660 & 40.89 & 0.9922 \\
\hline $\mathrm{R} 3$ & 131.03 & 0.9881 & 77.00 & 0.9855 & 51.91 & 0.9632 & 42.50 & 0.9946 \\
\hline \multicolumn{9}{|l|}{ Diffusion models } \\
\hline D1 & $257 \cdot 38$ & 0.9822 & $145 \cdot 77$ & 0.9663 & 101.66 & 0.9757 & 82.02 & 0.9866 \\
\hline D2 & 263.50 & 0.9858 & 153.38 & 0.9771 & 106.75 & 0.9725 & 87.67 & 0.9918 \\
\hline D3 & 270.46 & 0.9890 & 163.05 & 0.9876 & 112.71 & 0.9675 & 94.16 & 0.9960 \\
\hline $\mathrm{D} 4$ & 265.82 & 0.9870 & 156.54 & 0.9811 & 108.73 & 0.9710 & 89.82 & 0.9934 \\
\hline \multicolumn{9}{|l|}{ Reaction-order models } \\
\hline Fo/R1 & 124.49 & 0.9808 & 68.36 & 0.9608 & 46.38 & 0.9720 & 36.43 & 0.9820 \\
\hline $\mathrm{F} 1$ & 134.64 & 0.9906 & 82.26 & 0.9930 & 55.03 & 0.9563 & 45.87 & 0.9980 \\
\hline F2 & 26.94 & 0.9900 & 19.93 & 0.9968 & 16.38 & 0.9917 & $15 \cdot 35$ & 0.9999 \\
\hline $\mathrm{F}_{3}$ & 160.94 & 0.9811 & 126.10 & 0.9450 & 78.60 & 0.8924 & 70.75 & 0.9910 \\
\hline
\end{tabular}


Un-leached $+\mathrm{H}$

\begin{tabular}{|c|c|c|c|c|c|c|c|c|}
\hline \multirow{3}{*}{ Reaction Model } & \multicolumn{8}{|c|}{ Heating Rates $\left(\mathrm{K} \mathrm{min}^{-1}\right)$} \\
\hline & \multicolumn{2}{|c|}{10} & \multicolumn{2}{|c|}{20} & \multicolumn{2}{|c|}{30} & \multicolumn{2}{|c|}{50} \\
\hline & $\mathrm{Ea} \mathrm{kJ} \mathrm{mol}^{-1}$ & $\mathrm{R}^{2}$ & $\mathrm{Ea} \mathrm{kJ} \mathrm{mol}^{-1}$ & $\mathrm{R}^{2}$ & Ea kJ mol$^{-1}$ & $\mathrm{R}^{2}$ & Ea kJ mol-1 & $\mathrm{R}^{2}$ \\
\hline \multicolumn{9}{|l|}{ Nucleation models } \\
\hline Po.7 & $7.48 \mathrm{E}-04$ & 0.9833 & $4.99 \mathrm{E}-04$ & 0.9430 & $4.99 \mathrm{E}-04$ & 0.9774 & $4.16 \mathrm{E}-04$ & 0.9988 \\
\hline P2 & $2.49 \mathrm{E}-04$ & 0.9833 & $1.66 \mathrm{E}-04$ & 0.9430 & $1.66 \mathrm{E}-04$ & 0.9774 & $1.66 \mathrm{E}-04$ & 0.9988 \\
\hline $\mathrm{P}_{3}$ & $1.66 \mathrm{E}-04$ & 0.9833 & $8.31 \mathrm{E}-05$ & 0.9430 & $8.31 \mathrm{E}-05$ & 0.9774 & $8.31 \mathrm{E}-05$ & 0.9988 \\
\hline P4 & $1.66 \mathrm{E}-04$ & 0.9833 & $8.31 \mathrm{E}-05$ & 0.9430 & $8.31 \mathrm{E}-05$ & 0.9774 & $6.65 \mathrm{E}-05$ & 0.9988 \\
\hline A1.5 & 74.96 & 0.9974 & 52.33 & 0.9969 & 40.91 & 0.9958 & 37.80 & 0.9748 \\
\hline A2 & 54.09 & 0.9973 & 36.99 & 0.9962 & 28.47 & 0.9953 & 26.07 & 0.9713 \\
\hline A3 & 33.22 & 0.9969 & 21.65 & 0.9944 & 16.03 & 0.9940 & 14.33 & 0.9609 \\
\hline A4 & 22.78 & 0.9963 & 13.98 & 0.9914 & 9.81 & 0.9915 & 8.47 & 0.9422 \\
\hline \multicolumn{9}{|l|}{ Geometrical contraction models } \\
\hline R2 & 110.24 & 0.9985 & 75.63 & 0.9887 & 61.81 & 0.9957 & 57.18 & 0.9842 \\
\hline $\mathrm{R}_{3}$ & 112.33 & 0.9985 & 77.94 & 0.9926 & 63.09 & 0.9961 & 58.51 & 0.9821 \\
\hline \multicolumn{9}{|l|}{ Diffusion models } \\
\hline D1 & 217.34 & 0.9969 & 148.21 & 0.9771 & 125.24 & 0.9939 & 115.95 & 0.9909 \\
\hline D2 & 224.75 & 0.9983 & 155.55 & 0.9858 & 129.83 & 0.9956 & 120.79 & 0.9878 \\
\hline D3 & 233.18 & 0.9986 & 164.89 & 0.9937 & 135.04 & 0.9965 & 126.16 & 0.9840 \\
\hline D4 & 227.55 & 0.9986 & 158.61 & 0.9889 & 131.55 & 0.9960 & 122.57 & 0.9865 \\
\hline \multicolumn{9}{|l|}{ Reaction-order models } \\
\hline Fo/R1 & 104.41 & 0.9965 & 69.59 & 0.9733 & 58.20 & 0.9927 & 53.40 & 0.9898 \\
\hline F1 & 116.70 & 0.9976 & 83.01 & 0.9974 & 65.79 & 0.9962 & 61.27 & 0.9777 \\
\hline F2 & 23.84 & 0.9990 & 20.06 & 0.9983 & 17.92 & 0.9992 & 17.47 & 0.9961 \\
\hline$F_{3}$ & 148.67 & 0.9634 & 125.23 & 0.9379 & 85.45 & 0.9734 & 80.71 & 0.9465 \\
\hline
\end{tabular}


Un-leached + H-71

\begin{tabular}{|c|c|c|c|c|c|c|c|c|}
\hline \multirow{3}{*}{ Reaction Model } & \multicolumn{8}{|c|}{ Heating Rates $\left(\mathrm{K} \mathrm{min}^{-1}\right)$} \\
\hline & \multicolumn{2}{|c|}{10} & \multicolumn{2}{|c|}{20} & \multicolumn{2}{|c|}{30} & \multicolumn{2}{|c|}{50} \\
\hline & Ea kJ mol-11 & $\mathrm{R}^{2}$ & $\mathrm{Ea} \mathrm{kJ} \mathrm{mol}^{-1}$ & $\mathrm{R}^{2}$ & Ea kJ mol-11 & $\mathrm{R}^{2}$ & $\mathrm{Ea} \mathrm{kJ} \mathrm{mol}^{-1}$ & $\mathrm{R}^{2}$ \\
\hline \multicolumn{9}{|l|}{ Nucleation models } \\
\hline Po.7 & $8.31 \mathrm{E}-\mathrm{O} 4$ & 0.9875 & $4.99 \mathrm{E}-04$ & 0.9523 & $4.99 \mathrm{E}-\mathrm{O} 4$ & 0.9441 & $4.16 \mathrm{E}-\mathrm{O} 4$ & 0.9543 \\
\hline $\mathrm{P} 2$ & $2.49 \mathrm{E}-\mathrm{O} 4$ & 0.9875 & $1.66 \mathrm{E}-04$ & 0.9523 & $1.66 \mathrm{E}-04$ & 0.9441 & $1.66 \mathrm{E}-04$ & 0.9543 \\
\hline $\mathrm{P}_{3}$ & $1.66 \mathrm{E}-04$ & 0.9875 & $8.31 \mathrm{E}-05$ & 0.9523 & $8.31 \mathrm{E}-\mathrm{O} 5$ & 0.9441 & $8.31 \mathrm{E}-05$ & 0.9543 \\
\hline $\mathrm{P}_{4}$ & $1.66 \mathrm{E}-04$ & 0.9875 & $8.31 \mathrm{E}-\mathrm{O} 5$ & 0.9523 & 8.31E-05 & 0.9441 & $6.65 \mathrm{E}-05$ & 0.9543 \\
\hline A1.5 & 75.21 & 0.9978 & 51.08 & 0.9987 & $45 \cdot 35$ & 0.9899 & 38.79 & 0.9889 \\
\hline A2 & $54 \cdot 33$ & 0.9977 & 36.05 & 0.9986 & 31.80 & 0.9878 & 26.81 & 0.9863 \\
\hline A3 & 33.45 & 0.9975 & 21.02 & 0.9981 & 18.24 & 0.9819 & 14.82 & 0.9784 \\
\hline A4 & 23.01 & 0.9973 & 13.51 & 0.9973 & 11.47 & 0.9719 & 8.83 & 0.9632 \\
\hline \multicolumn{9}{|l|}{ Geometrical contraction models } \\
\hline $\mathrm{R} 2$ & 111.96 & 0.9997 & 72.58 & 0.9946 & 68.09 & 0.9831 & 57.28 & 0.9812 \\
\hline $\mathrm{R}_{3}$ & 113.59 & 0.9994 & 75.21 & 0.9975 & 69.49 & 0.9862 & 59.04 & 0.9848 \\
\hline \multicolumn{9}{|l|}{ Diffusion models } \\
\hline D1 & 223.13 & 0.9994 & 140.70 & 0.9834 & 137.17 & 0.9762 & 113.86 & 0.9736 \\
\hline D2 & 228.94 & 0.9998 & 148.77 & 0.9915 & 142.15 & 0.9824 & 120.09 & 0.9808 \\
\hline D3 & 235.49 & 0.9994 & 159.47 & 0.9979 & 147.85 & 0.9883 & 127.24 & 0.9874 \\
\hline $\mathrm{D} 4$ & 231.12 & 0.9998 & 152.25 & 0.9943 & 144.04 & 0.9846 & 122.46 & 0.9832 \\
\hline \multicolumn{9}{|l|}{ Reaction-order models } \\
\hline Fo/R1 & 107.41 & 0.9994 & 65.83 & 0.9803 & 64.16 & 0.9720 & 52.35 & 0.9680 \\
\hline $\mathrm{F} 1$ & 116.98 & 0.9979 & 81.15 & 0.9988 & 72.46 & 0.9916 & 62.77 & 0.9909 \\
\hline F2 & 24.17 & 0.9997 & 19.65 & 0.9996 & 18.83 & 0.9972 & 17.47 & 0.9984 \\
\hline $\mathrm{F}_{3}$ & 141.44 & 0.9659 & 132.77 & 0.8956 & 94.33 & 0.9932 & 90.29 & 0.9974 \\
\hline
\end{tabular}


Un-leached + H-31

\begin{tabular}{|c|c|c|c|c|c|c|c|c|}
\hline \multirow{3}{*}{ Reaction Model } & \multicolumn{8}{|c|}{ Heating Rates $\left(\mathrm{K} \mathrm{min}^{-1}\right)$} \\
\hline & \multicolumn{2}{|c|}{10} & \multicolumn{2}{|c|}{20} & \multicolumn{2}{|c|}{30} & \multicolumn{2}{|c|}{50} \\
\hline & $\mathrm{Ea} \mathrm{kJ} \mathrm{mol}^{-1}$ & $\mathrm{R}^{2}$ & $\mathrm{Ea} \mathrm{kJ} \mathrm{mol}^{-1}$ & $\mathrm{R}^{2}$ & Ea kJ mol$^{-1}$ & $\mathrm{R}^{2}$ & Ea kJ mol-1 & $\mathrm{R}^{2}$ \\
\hline \multicolumn{9}{|l|}{ Nucleation models } \\
\hline Po.7 & $8.31 \mathrm{E}-04$ & 0.9801 & $4.99 \mathrm{E}-04$ & 0.9473 & $4.99 \mathrm{E}-04$ & 0.9370 & $4.16 \mathrm{E}-04$ & 0.9528 \\
\hline P2 & $3.33 \mathrm{E}-04$ & 0.9801 & $1.66 \mathrm{E}-04$ & 0.9473 & $1.66 \mathrm{E}-04$ & 0.9370 & $1.66 \mathrm{E}-04$ & 0.9528 \\
\hline $\mathrm{P}_{3}$ & $1.66 \mathrm{E}-04$ & 0.9801 & 8.31E-05 & 0.9473 & $8.31 \mathrm{E}-05$ & 0.9370 & $8.31 \mathrm{E}-05$ & 0.9528 \\
\hline P4 & $1.66 \mathrm{E}-04$ & 0.9801 & $7.48 \mathrm{E}-05$ & 0.9473 & $8.31 \mathrm{E}-05$ & 0.9370 & $7.48 \mathrm{E}-05$ & 0.9528 \\
\hline A1.5 & 81.31 & 0.9967 & 48.13 & 0.9988 & 45.85 & 0.9855 & 42.96 & 0.9882 \\
\hline A2 & 58.90 & 0.9964 & 33.84 & 0.9985 & 32.17 & 0.9827 & 29.94 & 0.9858 \\
\hline A3 & 36.49 & 0.9959 & 19.55 & 0.9977 & 18.49 & 0.9749 & 16.91 & 0.9788 \\
\hline A4 & 25.29 & 0.9952 & 12.41 & 0.9963 & 11.65 & 0.9620 & 10.39 & 0.9664 \\
\hline \multicolumn{9}{|l|}{ Geometrical contraction models } \\
\hline R2 & 121.17 & 0.9972 & 68.40 & 0.9925 & 68.71 & 0.9976 & 63.42 & 0.9805 \\
\hline $\mathrm{R}_{3}$ & 122.76 & 0.9973 & 70.96 & 0.9961 & 70.16 & 0.9813 & 65.22 & 0.9841 \\
\hline \multicolumn{9}{|l|}{ Diffusion models } \\
\hline D1 & 241.63 & 0.9959 & 132.62 & 0.9799 & 138.25 & 0.9701 & 125.93 & 0.9728 \\
\hline D2 & 247.38 & 0.9971 & 140.54 & 0.9891 & 143.33 & 0.9772 & 132.28 & 0.9799 \\
\hline D3 & 253.85 & 0.9975 & 150.96 & 0.9968 & 149.19 & 0.9841 & 139.58 & 0.9866 \\
\hline D4 & 249.53 & 0.9973 & 143.94 & 0.9923 & 145.27 & 0.9797 & 134.70 & 0.9823 \\
\hline \multicolumn{9}{|l|}{ Reaction-order models } \\
\hline Fo/R1 & 116.65 & 0.9956 & 61.79 & 0.9761 & 64.69 & 0.9649 & 58.39 & 0.9676 \\
\hline F1 & 126.12 & 0.9969 & 76.71 & 0.9989 & 73.21 & 0.9877 & 69.02 & 0.9902 \\
\hline F2 & 25.56 & 0.9975 & 19.05 & 0.9995 & 18.92 & 0.9960 & 18.29 & 0.9977 \\
\hline$F_{3}$ & 150.20 & 0.9724 & 126.19 & 0.9062 & 95.77 & 0.9942 & 97.12 & 0.9978 \\
\hline
\end{tabular}


Un-leached + H-11

\begin{tabular}{|c|c|c|c|c|c|c|c|c|}
\hline \multirow{3}{*}{ Reaction Model } & \multicolumn{8}{|c|}{ Heating Rates $\left(\mathrm{K} \mathrm{min}^{-1}\right)$} \\
\hline & \multicolumn{2}{|c|}{10} & \multicolumn{2}{|c|}{20} & \multicolumn{2}{|c|}{30} & \multicolumn{2}{|c|}{50} \\
\hline & $\mathrm{Ea} \mathrm{kJ} \mathrm{mol}^{-1}$ & $\mathrm{R}^{2}$ & $\mathrm{Ea} \mathrm{kJ} \mathrm{mol}^{-1}$ & $\mathrm{R}^{2}$ & $\mathrm{Ea} \mathrm{kJ} \mathrm{mol}^{-1}$ & $\mathrm{R}^{2}$ & $\mathrm{Ea} \mathrm{kJ} \mathrm{mol}^{-1}$ & $\mathrm{R}^{2}$ \\
\hline \multicolumn{9}{|l|}{ Nucleation models } \\
\hline Po.7 & $8.31 \mathrm{E}-04$ & 0.9816 & $4.16 \mathrm{E}-04$ & 0.9622 & $5.82 \mathrm{E}-04$ & 0.9622 & $2.49 \mathrm{E}-04$ & $0.975^{2}$ \\
\hline P2 & $2.49 \mathrm{E}-04$ & 0.9816 & $1.66 \mathrm{E}-04$ & 0.9622 & $1.66 \mathrm{E}-04$ & 0.9622 & $8.31 \mathrm{E}-05$ & 0.9752 \\
\hline $\mathrm{P}_{3}$ & $1.66 \mathrm{E}-04$ & 0.9816 & $8.31 \mathrm{E}-05$ & 0.9622 & $1.66 \mathrm{E}-04$ & 0.9622 & $5.82 \mathrm{E}-05$ & $0.975^{2}$ \\
\hline P4 & $1.66 \mathrm{E}-04$ & 0.9816 & 8.31E-05 & 0.9770 & $8.31 \mathrm{E}-05$ & 0.9622 & $4.16 \mathrm{E}-05$ & 0.9752 \\
\hline A1.5 & 86.42 & 0.9988 & 48.04 & 0.9938 & 52.30 & 0.9957 & 15.36 & 0.9781 \\
\hline A2 & 62.65 & 0.9987 & 33.71 & 0.9926 & 37.00 & 0.9950 & 9.24 & 0.9635 \\
\hline A3 & 38.88 & 0.9985 & 19.37 & 0.9892 & 21.71 & 0.9930 & 3.13 & 0.8534 \\
\hline A4 & 26.99 & 0.9983 & 12.21 & 0.9835 & 14.07 & 0.9898 & 0.07 & 0.0044 \\
\hline \multicolumn{9}{|l|}{ Geometrical contraction models } \\
\hline $\mathrm{R} 2$ & $125 \cdot 34$ & 0.9976 & 66.33 & 0.9798 & 79.06 & 0.9933 & 26.01 & 0.9816 \\
\hline $\mathrm{R}_{3}$ & 128.12 & 0.9984 & 69.55 & 0.9863 & 80.29 & 0.9945 & 26.53 & 0.9831 \\
\hline \multicolumn{9}{|l|}{ Diffusion models } \\
\hline D1 & 243.85 & 0.9938 & 125.28 & 0.9603 & 160.03 & 0.9902 & 58.07 & 0.9845 \\
\hline D2 & 253.66 & 0.9966 & $135 \cdot 33$ & 0.9750 & 164.45 & 0.9930 & 60.06 & 0.9866 \\
\hline D3 & 264.90 & 0.9985 & 148.40 & 0.9884 & 169.45 & 0.9953 & 62.16 & 0.9887 \\
\hline D4 & 257.39 & 0.9974 & 139.60 & 0.9802 & 166.11 & 0.9938 & 60.76 & 0.9873 \\
\hline \multicolumn{9}{|l|}{ Reaction-order models } \\
\hline Fo/R1 & 117.59 & 0.9932 & 57.99 & 0.9529 & 75.58 & 0.9886 & 24.48 & 0.9765 \\
\hline F1 & 133.96 & 0.9989 & 76.70 & 0.9947 & 82.88 & 0.9963 & 27.59 & 0.9859 \\
\hline $\mathrm{F}_{2}$ & $25 \cdot 74$ & 0.9986 & 18.93 & 0.9981 & 20.49 & 0.9982 & 13.45 & 0.9999 \\
\hline$F_{3}$ & 177.03 & 0.9720 & 137.56 & 0.9368 & 101.55 & 0.9869 & 34.53 & 0.9965 \\
\hline
\end{tabular}


Un-leached $+\mathrm{H}-13$

\begin{tabular}{|c|c|c|c|c|c|c|c|c|}
\hline \multirow{3}{*}{ Reaction Model } & \multicolumn{8}{|c|}{ Heating Rates $\left(\mathrm{K} \mathrm{min}^{-1}\right)$} \\
\hline & \multicolumn{2}{|c|}{10} & \multicolumn{2}{|c|}{20} & \multicolumn{2}{|c|}{30} & \multicolumn{2}{|c|}{50} \\
\hline & $\mathrm{Ea} \mathrm{kJ} \mathrm{mol}^{-1}$ & $\mathrm{R}^{2}$ & $\mathrm{Ea} \mathrm{kJ} \mathrm{mol}^{-1}$ & $\mathrm{R}^{2}$ & $\mathrm{Ea} \mathrm{kJ} \mathrm{mol}^{-1}$ & $\mathrm{R}^{2}$ & $\mathrm{Ea} \mathrm{kJ} \mathrm{mol}^{-1}$ & $\mathrm{R}^{2}$ \\
\hline \multicolumn{9}{|l|}{ Nucleation models } \\
\hline Po.7 & $8.31 \mathrm{E}-04$ & 0.9677 & $4.99 \mathrm{E}-04$ & 0.9220 & $4.16 \mathrm{E}-04$ & 0.9276 & $3.33 \mathrm{E}-04$ & 0.9412 \\
\hline P2 & 3.33E-04 & 0.9677 & $1.66 \mathrm{E}-04$ & 0.9220 & $1.66 \mathrm{E}-04$ & 0.9276 & $8.31 \mathrm{E}-05$ & 0.9412 \\
\hline $\mathrm{P}_{3}$ & $1.66 \mathrm{E}-04$ & 0.9677 & 8.31E-05 & 0.9220 & $8.31 \mathrm{E}-05$ & 0.9276 & $7.48 \mathrm{E}-05$ & 0.9412 \\
\hline $\mathrm{P}_{4}$ & $1.66 \mathrm{E}-04$ & 0.9677 & 7.48E-05 & 0.9220 & $7.48 \mathrm{E}-05$ & 0.9276 & $5.82 \mathrm{E}-05$ & 0.9412 \\
\hline A1.5 & 81.17 & 0.9968 & 48.40 & 0.9908 & 39.21 & 0.9808 & 34.72 & 0.9765 \\
\hline A2 & 58.81 & 0.9965 & 34.05 & 0.9891 & 27.20 & 0.9766 & 23.75 & 0.9709 \\
\hline A3 & 36.44 & 0.9957 & 19.69 & 0.9844 & 15.18 & 0.9641 & 12.79 & 0.9530 \\
\hline A4 & 25.25 & 0.9947 & 12.51 & 0.9766 & 9.17 & 0.9415 & 7.31 & 0.9167 \\
\hline \multicolumn{9}{|l|}{ Geometrical contraction models } \\
\hline $\mathrm{R} 2$ & 120.21 & 0.9936 & 68.44 & 0.9766 & 58.33 & 0.9704 & 50.86 & 0.9660 \\
\hline $\mathrm{R}_{3}$ & 122.05 & 0.9950 & 71.12 & 0.9832 & 59.90 & 0.9754 & 52.72 & 0.9714 \\
\hline \multicolumn{9}{|l|}{ Diffusion models } \\
\hline D1 & 238.44 & 0.9890 & 132.13 & 0.9586 & 116.80 & 0.9608 & 100.55 & 0.9569 \\
\hline D2 & 244.96 & 0.9924 & 140.39 & 0.9723 & 122.27 & 0.9702 & 107.03 & 0.9668 \\
\hline D3 & 252.39 & 0.9954 & 151.26 & 0.9856 & 128.66 & 0.9794 & 114.58 & 0.9764 \\
\hline D4 & 247.42 & 0.9936 & 143.94 & 0.9774 & 124.39 & 0.9736 & 109.54 & 0.9703 \\
\hline \multicolumn{9}{|l|}{ Reaction-order models } \\
\hline Fo/R1 & 115.07 & 0.9879 & 61.55 & 0.9514 & 53.97 & 0.9530 & 45.70 & 0.9469 \\
\hline F1 & 125.91 & 0.9971 & 77.12 & 0.9921 & 91.21 & 0.9615 & 56.65 & 0.9807 \\
\hline $\mathrm{F} 2$ & $25 \cdot 32$ & 0.9954 & 19.06 & 0.9968 & 17.43 & 0.9964 & 16.61 & 0.9974 \\
\hline F3 & 154.19 & 0.9837 & 128.96 & 0.9251 & 88.46 & 0.9925 & 86.16 & 0.9996 \\
\hline
\end{tabular}


Un-leached + A

\begin{tabular}{|c|c|c|c|c|c|c|c|c|}
\hline \multirow{3}{*}{ Reaction Model } & \multicolumn{8}{|c|}{ Heating Rates $\left(\mathrm{K} \mathrm{min}^{-1}\right)$} \\
\hline & \multicolumn{2}{|c|}{10} & \multicolumn{2}{|c|}{20} & \multicolumn{2}{|c|}{30} & \multicolumn{2}{|c|}{50} \\
\hline & Ea kJ mol$^{-1}$ & $\mathrm{R}^{2}$ & Ea kJ mol-1 & $\mathrm{R}^{2}$ & $\mathrm{Ea} \mathrm{kJ} \mathrm{mol}^{-1}$ & $\mathrm{R}^{2}$ & $\mathrm{Ea} \mathrm{kJ} \mathrm{mol}^{-1}$ & $\mathrm{R}^{2}$ \\
\hline \multicolumn{9}{|l|}{ Nucleation models } \\
\hline Po.7 & $8.31 \mathrm{E}-04$ & 0.9681 & $4.16 \mathrm{E}-\mathrm{O} 4$ & 0.9226 & $4.99 \mathrm{E}-04$ & 0.9203 & $3.33 \mathrm{E}-04$ & 0.9847 \\
\hline $\mathrm{P} 2$ & $2.49 \mathrm{E}-04$ & 0.9681 & $1.66 \mathrm{E}-\mathrm{O} 4$ & 0.9226 & $1.66 \mathrm{E}-04$ & 0.9203 & 8.31E-05 & 0.9847 \\
\hline $\mathrm{P}_{3}$ & $1.66 \mathrm{E}-04$ & 0.9681 & $8.31 \mathrm{E}-05$ & 0.9226 & $8.31 \mathrm{E}-\mathrm{O} 5$ & 0.9203 & $7.48 \mathrm{E}-05$ & 0.9847 \\
\hline $\mathrm{P}_{4}$ & $1.66 \mathrm{E}-04$ & 0.9681 & $7 \cdot 48 \mathrm{E}-\mathrm{O} 5$ & 0.9226 & 8.31E-05 & 0.9203 & $5.82 \mathrm{E}-\mathrm{O} 5$ & 0.9847 \\
\hline A1.5 & 82.29 & 0.9960 & 46.19 & 0.9894 & 43.36 & 0.9712 & 29.45 & 0.9994 \\
\hline A2 & 59.58 & 0.9956 & 32.38 & 0.9874 & 30.30 & 0.9661 & 19.80 & 0.9995 \\
\hline A3 & 36.87 & 0.9947 & 18.57 & 0.9817 & 17.25 & 0.9517 & 10.15 & 0.9996 \\
\hline A4 & $25 \cdot 52$ & 0.9935 & 11.67 & 0.9719 & 10.72 & 0.9277 & $5 \cdot 32$ & 0.9998 \\
\hline \multicolumn{9}{|l|}{ Geometrical contraction models } \\
\hline $\mathrm{R} 2$ & 120.62 & 0.9923 & 65.89 & 0.9755 & 64.76 & 0.9624 & 44.52 & 0.9999 \\
\hline $\mathrm{R} 3$ & 122.90 & 0.9940 & 68.36 & 0.9819 & 66.27 & 0.9671 & 45.89 & 1.0000 \\
\hline \multicolumn{9}{|l|}{ Diffusion models } \\
\hline D1 & 237.03 & 0.9868 & 127.93 & 0.9590 & 130.01 & 0.9541 & 90.42 & 0.9987 \\
\hline D2 & 245.11 & 0.9910 & 135.74 & 0.9721 & 135.29 & 0.9631 & $95 \cdot 39$ & 0.9997 \\
\hline D3 & 254.33 & 0.9945 & 145.75 & 0.9846 & 141.40 & 0.9717 & 100.93 & 1.0000 \\
\hline $\mathrm{D} 4$ & 248.16 & 0.9923 & 139.03 & 0.9768 & 137.32 & 0.9662 & 97.22 & 0.9999 \\
\hline \multicolumn{9}{|l|}{ Reaction-order models } \\
\hline Fo/R1 & 114.25 & 0.9856 & 59.44 & 0.9516 & 60.57 & 0.9463 & 40.64 & 0.9981 \\
\hline $\mathrm{F} 1$ & 127.69 & 0.9963 & 73.80 & 0.9911 & 69.46 & 0.9753 & 48.75 & 0.9994 \\
\hline F2 & 25.28 & 0.9955 & 18.69 & 0.9968 & 18.36 & 0.9929 & 15.80 & 0.9998 \\
\hline $\mathrm{F}_{3}$ & 163.05 & 0.9793 & 119.39 & 0.9451 & 93.27 & 0.9868 & 69.17 & 0.9816 \\
\hline
\end{tabular}


Leached biomass

\begin{tabular}{|c|c|c|c|c|c|c|c|c|}
\hline \multirow{3}{*}{ Reaction Model } & \multicolumn{8}{|c|}{ Heating Rates $\left(\mathrm{K} \mathrm{min}^{-1}\right)$} \\
\hline & \multicolumn{2}{|c|}{10} & \multicolumn{2}{|c|}{20} & \multicolumn{2}{|c|}{30} & \multicolumn{2}{|c|}{50} \\
\hline & $\mathrm{Ea} \mathrm{kJ} \mathrm{mol}^{-1}$ & $\mathrm{R}^{2}$ & $\mathrm{Ea} \mathrm{kJ} \mathrm{mol}^{-1}$ & $\mathrm{R}^{2}$ & $\mathrm{Ea} \mathrm{kJ} \mathrm{mol}^{-1}$ & $\mathrm{R}^{2}$ & $\mathrm{Ea} \mathrm{kJ} \mathrm{mol}^{-1}$ & $\mathrm{R}^{2}$ \\
\hline \multicolumn{9}{|l|}{ Nucleation models } \\
\hline Po.7 & $8.31 \mathrm{E}-04$ & 0.9882 & $5.82 \mathrm{E}-04$ & 0.9259 & $1.66 \mathrm{E}-04$ & 0.8052 & $3.33 \mathrm{E}-04$ & 0.9730 \\
\hline P2 & $2.49 \mathrm{E}-04$ & 0.9624 & $1.66 \mathrm{E}-04$ & 0.9259 & 5.82E-05 & 0.8052 & $8.31 \mathrm{E}-05$ & 0.9730 \\
\hline $\mathrm{P}_{3}$ & $1.66 \mathrm{E}-04$ & 0.9624 & $1.66 \mathrm{E}-04$ & 0.9259 & $4.16 \mathrm{E}-05$ & 0.8052 & 7.48E-05 & 0.9730 \\
\hline $\mathrm{P}_{4}$ & $8.31 \mathrm{E}-05$ & 0.9624 & $8.31 \mathrm{E}-05$ & 0.9259 & $2.49 \mathrm{E}-05$ & 0.8052 & $5.82 \mathrm{E}-05$ & 0.9730 \\
\hline A1.5 & 75.97 & 0.9957 & 58.16 & 0.9868 & 9.88 & 0.2670 & 30.62 & 0.9995 \\
\hline A2 & 54.80 & 0.9952 & 41.36 & 0.9848 & 5.19 & 0.1534 & 20.68 & 0.9991 \\
\hline A3 & 33.63 & 0.9941 & 24.55 & 0.9797 & 0.50 & 0.0039 & 10.74 & 0.9978 \\
\hline A4 & 23.05 & 0.9925 & 16.14 & 0.9721 & 1.84 & 0.0879 & 5.77 & 0.9938 \\
\hline \multicolumn{9}{|l|}{ Geometrical contraction models } \\
\hline $\mathrm{R} 2$ & 110.80 & 0.9897 & 84.87 & 0.9758 & 15.80 & 0.3404 & $45 \cdot 45$ & 0.9964 \\
\hline $\mathrm{R}_{3}$ & 113.21 & 0.9922 & 87.04 & 0.9807 & 16.91 & 0.3536 & 47.08 & 0.9979 \\
\hline \multicolumn{9}{|l|}{ Diffusion models } \\
\hline D1 & 216.87 & 0.9821 & 167.28 & 0.9635 & 34.43 & 0.4294 & 90.98 & 0.9918 \\
\hline D2 & $225 \cdot 36$ & 0.9878 & 174.34 & 0.9733 & 38.22 & 0.4462 & 96.71 & 0.9957 \\
\hline D3 & 235.14 & 0.9929 & 183.15 & 0.9830 & 42.69 & 0.4622 & 103.28 & 0.9985 \\
\hline D4 & 228.60 & 0.9897 & 177.24 & 0.9769 & 39.70 & 0.4519 & 98.90 & 0.9968 \\
\hline \multicolumn{9}{|l|}{ Reaction-order models } \\
\hline Fo/R1 & 104.08 & 0.9804 & 79.11 & 0.9585 & 12.78 & 0.2964 & 40.92 & 0.9892 \\
\hline F1 & 118.31 & 0.9962 & 91.78 & 0.9884 & 19.25 & 0.3777 & 50.50 & 0.9997 \\
\hline F2 & 24.05 & 0.9958 & 20.40 & 0.9936 & 11.91 & 0.9367 & 15.91 & 1.0000 \\
\hline F3 & 156.13 & 0.9861 & 130.46 & 0.9591 & 37.19 & 0.4667 & 75.74 & 0.9857 \\
\hline
\end{tabular}


Leached $+\mathrm{H}$

\begin{tabular}{|c|c|c|c|c|c|c|c|c|}
\hline \multirow{3}{*}{ Reaction Model } & \multicolumn{8}{|c|}{ Heating Rates $\left(\mathrm{K} \mathrm{min}^{-1}\right)$} \\
\hline & \multicolumn{2}{|c|}{10} & \multicolumn{2}{|c|}{20} & \multicolumn{2}{|c|}{30} & \multicolumn{2}{|c|}{50} \\
\hline & Ea kJ mol-11 & $\mathrm{R}^{2}$ & Ea kJ mol-1 & $\mathrm{R}^{2}$ & Ea kJ mol-1 & $\mathrm{R}^{2}$ & $\mathrm{Ea} \mathrm{kJ} \mathrm{mol}^{-1}$ & $\mathrm{R}^{2}$ \\
\hline \multicolumn{9}{|l|}{ Nucleation models } \\
\hline Po.7 & $7.48 \mathrm{E}-\mathrm{O} 4$ & 0.9887 & $4.99 \mathrm{E}-\mathrm{O} 4$ & 0.9377 & $3 \cdot 33 \mathrm{E}-\mathrm{O} 4$ & 0.9249 & $4.16 \mathrm{E}-\mathrm{O} 4$ & 0.9973 \\
\hline $\mathrm{P} 2$ & $2.49 \mathrm{E}-04$ & 0.9887 & $1.66 \mathrm{E}-\mathrm{O} 4$ & 0.9377 & $8.31 \mathrm{E}-\mathrm{O} 5$ & 0.9249 & $1.66 \mathrm{E}-04$ & 0.9973 \\
\hline $\mathrm{P}_{3}$ & $1.66 \mathrm{E}-04$ & 0.9887 & $8.31 \mathrm{E}-05$ & 0.9377 & $7.48 \mathrm{E}-\mathrm{O} 5$ & 0.9249 & $8.31 \mathrm{E}-05$ & 0.9973 \\
\hline $\mathrm{P}_{4}$ & $1.66 \mathrm{E}-04$ & 0.9887 & $8.31 \mathrm{E}-\mathrm{O} 5$ & 0.9377 & $5.82 \mathrm{E}-\mathrm{O} 5$ & 0.9249 & $6.65 \mathrm{E}-05$ & 0.9973 \\
\hline A1.5 & 81.50 & 0.9972 & 51.90 & 0.9961 & 28.64 & 0.7569 & 38.17 & 0.9806 \\
\hline A2 & 58.96 & 0.9971 & 36.67 & 0.9953 & 19.26 & 0.7171 & 26.34 & 0.9780 \\
\hline A3 & 36.41 & 0.9967 & 21.44 & 0.9931 & 9.88 & 0.6061 & 14.52 & 0.9704 \\
\hline A4 & 25.14 & 0.9963 & 13.82 & 0.9895 & 5.18 & 0.4363 & 8.61 & 0.9568 \\
\hline \multicolumn{9}{|l|}{ Geometrical contraction models } \\
\hline $\mathrm{R} 2$ & 118.61 & 0.9995 & 74.58 & 0.9864 & 43.68 & 0.7852 & 57.21 & 0.9893 \\
\hline $\mathrm{R}_{3}$ & 121.17 & 0.9992 & 77.00 & 0.9908 & 44.88 & 0.7868 & 58.70 & 0.9872 \\
\hline \multicolumn{9}{|l|}{ Diffusion models } \\
\hline D1 & 231.59 & 0.9985 & 145.54 & 0.9735 & 89.48 & 0.8105 & 115.14 & 0.9949 \\
\hline D2 & 240.63 & 0.9995 & 153.19 & 0.9832 & 93.77 & 0.8131 & 120.51 & 0.9921 \\
\hline D3 & 251.01 & 0.9992 & 163.03 & 0.9922 & 98.65 & 0.8148 & 126.54 & 0.9885 \\
\hline $\mathrm{D} 4$ & 244.07 & 0.9996 & 156.41 & 0.9867 & 95.39 & 0.8138 & 122.52 & 0.9910 \\
\hline \multicolumn{9}{|l|}{ Reaction-order models } \\
\hline Fo/R1 & 111.46 & 0.9983 & 68.26 & 0.9690 & 40.29 & 0.7785 & 53.01 & 0.9945 \\
\hline $\mathrm{F} 1$ & 126.58 & 0.9973 & 82.37 & 0.9967 & 47.41 & 0.7891 & 61.82 & 0.9827 \\
\hline F2 & 24.93 & 0.9997 & 19.92 & 0.9980 & 15.48 & 0.9579 & 17.46 & 0.9970 \\
\hline $\mathrm{F}_{3}$ & 166.60 & 0.9546 & 127.62 & 0.9400 & 65.81 & 0.7817 & 84.17 & 0.9491 \\
\hline
\end{tabular}


Leached $+\mathrm{H}-71$

\begin{tabular}{|c|c|c|c|c|c|c|c|c|}
\hline \multirow{3}{*}{ Reaction Model } & \multicolumn{8}{|c|}{ Heating Rates $\left(\mathrm{K} \mathrm{min}^{-1}\right)$} \\
\hline & \multicolumn{2}{|c|}{10} & \multicolumn{2}{|c|}{20} & \multicolumn{2}{|c|}{30} & \multicolumn{2}{|c|}{50} \\
\hline & $\mathrm{Ea} \mathrm{kJ} \mathrm{mol}^{-1}$ & $\mathrm{R}^{2}$ & $\mathrm{Ea} \mathrm{kJ} \mathrm{mol}^{-1}$ & $\mathrm{R}^{2}$ & Ea kJ mol$^{-1}$ & $\mathrm{R}^{2}$ & Ea kJ mol-1 & $\mathrm{R}^{2}$ \\
\hline \multicolumn{9}{|l|}{ Nucleation models } \\
\hline Po.7 & $7.48 \mathrm{E}-04$ & 0.9936 & $4.99 \mathrm{E}-04$ & 0.9520 & $5.82 \mathrm{E}-04$ & 0.9476 & $4.16 \mathrm{E}-04$ & 0.9637 \\
\hline P2 & $2.49 \mathrm{E}-04$ & 0.9936 & $1.66 \mathrm{E}-04$ & 0.9520 & $1.66 \mathrm{E}-04$ & 0.9476 & $1.66 \mathrm{E}-04$ & 0.9637 \\
\hline $\mathrm{P}_{3}$ & $1.66 \mathrm{E}-04$ & 0.9936 & $8.31 \mathrm{E}-05$ & 0.9520 & $8.31 \mathrm{E}-05$ & 0.9476 & $8.31 \mathrm{E}-05$ & 0.9637 \\
\hline P4 & $1.66 \mathrm{E}-04$ & 0.9936 & 7.48E-05 & 0.9520 & $8.31 \mathrm{E}-05$ & 0.9476 & $6.65 \mathrm{E}-05$ & 0.9637 \\
\hline A1.5 & 65.97 & 0.9887 & 47.50 & 0.9986 & 48.36 & 0.9931 & 39.80 & 0.9956 \\
\hline A2 & 47.40 & 0.9880 & 33.37 & 0.9985 & 34.05 & 0.9917 & 27.56 & 0.9944 \\
\hline A3 & 28.82 & 0.9861 & 19.24 & 0.9981 & 19.74 & 0.9877 & 15.33 & 0.9908 \\
\hline A4 & 19.54 & 0.9837 & 12.17 & 0.9973 & 12.59 & 0.9813 & 9.21 & 0.9838 \\
\hline \multicolumn{9}{|l|}{ Geometrical contraction models } \\
\hline R2 & 98.16 & 0.9951 & 67.25 & 0.9953 & 72.45 & 0.9872 & 58.79 & 0.9899 \\
\hline $\mathrm{R}_{3}$ & 99.77 & 0.9935 & 69.87 & 0.9980 & 73.90 & 0.9899 & 60.55 & 0.9925 \\
\hline \multicolumn{9}{|l|}{ Diffusion models } \\
\hline D1 & 195.63 & 0.9982 & 130.16 & 0.9842 & 145.73 & 0.9807 & 116.87 & 0.9836 \\
\hline D2 & 201.37 & 0.9967 & 138.14 & 0.9923 & 150.81 & 0.9863 & 123.11 & 0.9891 \\
\hline D3 & 207.85 & 0.9939 & 148.76 & 0.9984 & 156.67 & 0.9914 & 130.26 & 0.9938 \\
\hline D4 & 203.53 & 0.9958 & 141.60 & 0.9950 & 152.74 & 0.9882 & 125.47 & 0.9909 \\
\hline \multicolumn{9}{|l|}{ Reaction-order models } \\
\hline Fo/R1 & 93.66 & 0.9981 & 60.56 & 0.9809 & 68.43 & 0.9774 & 53.86 & 0.9800 \\
\hline F1 & 103.12 & 0.9894 & 75.77 & 0.9987 & 76.96 & 0.9942 & 64.27 & 0.9964 \\
\hline F2 & 22.16 & 0.9986 & 18.91 & 0.9997 & 19.48 & 0.9974 & 17.67 & 0.9993 \\
\hline$F_{3}$ & 127.37 & 0.9403 & 127.30 & 0.8920 & 99.78 & 0.9871 & 91.74 & 0.9932 \\
\hline
\end{tabular}


Leached $+\mathrm{H}-31$

\begin{tabular}{|c|c|c|c|c|c|c|c|c|}
\hline \multirow{3}{*}{ Reaction Model } & \multicolumn{8}{|c|}{ Heating Rates $\left(\mathrm{K} \mathrm{min}^{-1}\right)$} \\
\hline & \multicolumn{2}{|c|}{10} & \multicolumn{2}{|c|}{20} & \multicolumn{2}{|c|}{30} & \multicolumn{2}{|c|}{50} \\
\hline & $\mathrm{Ea} \mathrm{kJ} \mathrm{mol}^{-1}$ & $\mathrm{R}^{2}$ & $\mathrm{Ea} \mathrm{kJ} \mathrm{mol}^{-1}$ & $\mathrm{R}^{2}$ & $\mathrm{Ea} \mathrm{kJ} \mathrm{mol}^{-1}$ & $\mathrm{R}^{2}$ & $\mathrm{Ea} \mathrm{kJ} \mathrm{mol}^{-1}$ & $\mathrm{R}^{2}$ \\
\hline \multicolumn{9}{|l|}{ Nucleation models } \\
\hline Po.7 & $7.48 \mathrm{E}-04$ & 0.9957 & $4.99 \mathrm{E}-04$ & 0.9678 & $4.99 \mathrm{E}-04$ & 0.9448 & $3 \cdot 33 \mathrm{E}-04$ & 0.9805 \\
\hline P2 & $2.49 \mathrm{E}-04$ & 0.9957 & $1.66 \mathrm{E}-04$ & 0.9678 & $1.66 \mathrm{E}-04$ & 0.9448 & $8.31 \mathrm{E}-05$ & 0.9805 \\
\hline $\mathrm{P}_{3}$ & $1.66 \mathrm{E}-04$ & 0.9957 & 8.31E-05 & 0.9678 & $8.31 \mathrm{E}-05$ & 0.9448 & $8.31 \mathrm{E}-05$ & 0.9805 \\
\hline $\mathrm{P}_{4}$ & $8.31 \mathrm{E}-05$ & 0.9957 & 8.31E-05 & 0.9678 & $7.48 \mathrm{E}-05$ & 0.9448 & $5.82 \mathrm{E}-05$ & 0.9805 \\
\hline A1.5 & 63.99 & 0.9845 & 48.84 & 0.9950 & 40.31 & 0.9940 & 35.88 & 0.9997 \\
\hline A2 & 45.91 & 0.9834 & 34.36 & 0.9946 & 28.03 & 0.9924 & 24.62 & 0.9997 \\
\hline A3 & 27.83 & 0.9807 & 19.88 & 0.9936 & 15.76 & 0.9878 & 13.37 & 0.9998 \\
\hline A4 & 18.79 & 0.9771 & 12.64 & 0.9919 & 9.62 & 0.9790 & 7.74 & 0.9999 \\
\hline \multicolumn{9}{|l|}{ Geometrical contraction models } \\
\hline R2 & 95.45 & 0.9923 & 69.99 & 0.9992 & 59.97 & 0.9868 & 52.87 & 0.9995 \\
\hline $\mathrm{R}_{3}$ & 96.97 & 0.9903 & 72.41 & 0.9993 & 61.53 & 0.9901 & 54.64 & 0.9999 \\
\hline \multicolumn{9}{|l|}{ Diffusion models } \\
\hline D1 & 190.66 & 0.9967 & 136.50 & 0.9939 & 120.15 & 0.9787 & 104.99 & 0.9969 \\
\hline D2 & 196.14 & 0.9944 & 144.09 & 0.9981 & 125.53 & 0.9856 & 111.23 & 0.9990 \\
\hline D3 & 202.28 & 0.9909 & 153.91 & 0.9994 & 131.86 & 0.9919 & 118.43 & 1.0000 \\
\hline D4 & 198.18 & 0.9933 & 147.30 & 0.9991 & 127.63 & 0.9880 & 113.62 & 0.9995 \\
\hline \multicolumn{9}{|l|}{ Reaction-order models } \\
\hline Fo/R1 & 91.17 & 0.9965 & 63.71 & 0.9925 & 55.68 & 0.9742 & 47.92 & 0.9959 \\
\hline $\mathrm{F} 1$ & 100.15 & 0.9855 & 77.80 & 0.9953 & 64.86 & 0.9952 & 58.39 & 0.9996 \\
\hline F2 & 21.80 & 0.9979 & 19.29 & 0.9996 & 17.62 & 0.9986 & 16.88 & 0.9999 \\
\hline$F_{3}$ & 122.93 & 0.9342 & 123.51 & 0.8778 & 90.18 & 0.9812 & 86.22 & 0.9763 \\
\hline
\end{tabular}


Leached $+\mathrm{H}-11$

\begin{tabular}{|c|c|c|c|c|c|c|c|c|}
\hline \multirow{3}{*}{ Reaction Model } & \multicolumn{8}{|c|}{ Heating Rates $\left(\mathrm{K} \mathrm{min}^{-1}\right)$} \\
\hline & \multicolumn{2}{|c|}{10} & \multicolumn{2}{|c|}{20} & \multicolumn{2}{|c|}{30} & \multicolumn{2}{|c|}{50} \\
\hline & $\mathrm{Ea} \mathrm{kJ} \mathrm{mol}^{-1}$ & $\mathrm{R}^{2}$ & $\mathrm{Ea} \mathrm{kJ} \mathrm{mol}^{-1}$ & $\mathrm{R}^{2}$ & $\mathrm{Ea} \mathrm{kJ} \mathrm{mol}^{-1}$ & $\mathrm{R}^{2}$ & $\mathrm{Ea} \mathrm{kJ} \mathrm{mol}^{-1}$ & $\mathrm{R}^{2}$ \\
\hline \multicolumn{9}{|l|}{ Nucleation models } \\
\hline Po.7 & $8.31 \mathrm{E}-04$ & 0.9685 & $4.16 \mathrm{E}-04$ & 0.9397 & $3.33 \mathrm{E}-04$ & 0.9956 & $4.16 \mathrm{E}-04$ & 0.9737 \\
\hline P2 & $2.49 \mathrm{E}-04$ & 0.9685 & $1.66 \mathrm{E}-04$ & 0.9397 & $8.31 \mathrm{E}-05$ & 0.9956 & $1.66 \mathrm{E}-04$ & 0.9737 \\
\hline $\mathrm{P}_{3}$ & $1.66 \mathrm{E}-04$ & 0.9685 & 8.31E-05 & 0.9397 & $6.65 \mathrm{E}-05$ & 0.9956 & $8.31 \mathrm{E}-05$ & 0.9737 \\
\hline $\mathrm{P}_{4}$ & $1.66 \mathrm{E}-04$ & 0.9685 & $6.65 \mathrm{E}-05$ & 0.9397 & $4.99 \mathrm{E}-05$ & 0.9956 & $6.65 \mathrm{E}-05$ & 0.9737 \\
\hline A1.5 & 90.46 & 0.9972 & 45.84 & 0.9961 & 23.45 & 0.8567 & 28.50 & 0.9871 \\
\hline A2 & 65.65 & 0.9969 & 32.05 & 0.9953 & $15 \cdot 38$ & 0.8243 & 19.08 & 0.9829 \\
\hline A3 & 40.85 & 0.9963 & 18.27 & 0.9929 & $7 \cdot 30$ & 0.7152 & 9.66 & 0.9675 \\
\hline A4 & 28.44 & 0.9955 & 11.38 & 0.9886 & 3.27 & 0.4855 & 4.95 & 0.9258 \\
\hline \multicolumn{9}{|l|}{ Geometrical contraction models } \\
\hline $\mathrm{R} 2$ & 129.02 & 0.9914 & 63.44 & 0.9847 & 36.07 & 0.8961 & 45.64 & 0.9872 \\
\hline $\mathrm{R}_{3}$ & 132.56 & 0.9939 & 66.54 & 0.9902 & 37.20 & 0.8911 & 46.20 & 0.9882 \\
\hline \multicolumn{9}{|l|}{ Diffusion models } \\
\hline D1 & $247 \cdot 30$ & 0.9829 & 120.01 & 0.9677 & 74.59 & 0.9261 & 97.17 & 0.9874 \\
\hline D2 & 259.55 & 0.9891 & 129.77 & 0.9805 & 78.64 & 0.9182 & 99.33 & 0.9891 \\
\hline D3 & 273.88 & 0.9944 & 142.36 & 0.9918 & 83.26 & 0.9087 & 101.58 & 0.9908 \\
\hline D4 & 264.29 & 0.9911 & 133.90 & 0.9850 & 80.17 & 0.9151 & 100.08 & 0.9897 \\
\hline \multicolumn{9}{|l|}{ Reaction-order models } \\
\hline Fo/R1 & 119.26 & 0.9814 & $55 \cdot 36$ & 0.9612 & 32.87 & 0.9098 & 43.99 & 0.9838 \\
\hline F1 & 140.07 & 0.9974 & 73.40 & 0.9967 & 39.60 & 0.8807 & $47 \cdot 34$ & 0.9901 \\
\hline F2 & 26.20 & 0.9963 & 18.54 & 0.9989 & 14.44 & 0.9828 & 16.15 & 0.9992 \\
\hline F3 & 196.91 & 0.9774 & 131.33 & 0.9398 & 57.07 & 0.8141 & 54.69 & 0.9977 \\
\hline
\end{tabular}


Leached $+\mathrm{H}-13$

\begin{tabular}{|c|c|c|c|c|c|c|c|c|}
\hline \multirow{3}{*}{ Reaction Model } & \multicolumn{8}{|c|}{ Heating Rates $\left(\mathrm{K} \mathrm{min}^{-1}\right)$} \\
\hline & \multicolumn{2}{|c|}{10} & \multicolumn{2}{|c|}{20} & \multicolumn{2}{|c|}{30} & \multicolumn{2}{|c|}{50} \\
\hline & $\mathrm{Ea} \mathrm{kJ} \mathrm{mol}^{-1}$ & $\mathrm{R}^{2}$ & $\mathrm{Ea} \mathrm{kJ} \mathrm{mol}^{-1}$ & $\mathrm{R}^{2}$ & $\mathrm{Ea} \mathrm{kJ} \mathrm{mol}^{-1}$ & $\mathrm{R}^{2}$ & $\mathrm{Ea} \mathrm{kJ} \mathrm{mol}^{-1}$ & $\mathrm{R}^{2}$ \\
\hline \multicolumn{9}{|l|}{ Nucleation models } \\
\hline Po.7 & $8.31 \mathrm{E}-04$ & 0.9874 & $4.99 \mathrm{E}-04$ & 0.9380 & $4.16 \mathrm{E}-04$ & 0.9531 & $3 \cdot 33 \mathrm{E}-04$ & 0.9764 \\
\hline P2 & $2.49 \mathrm{E}-04$ & 0.9874 & $1.66 \mathrm{E}-04$ & 0.9380 & $1.66 \mathrm{E}-04$ & 0.9531 & $8.31 \mathrm{E}-05$ & 0.9764 \\
\hline $\mathrm{P}_{3}$ & $1.66 \mathrm{E}-04$ & 0.9874 & $8.31 \mathrm{E}-05$ & 0.9380 & $8.31 \mathrm{E}-05$ & 0.9531 & $8.31 \mathrm{E}-05$ & 0.9764 \\
\hline $\mathrm{P}_{4}$ & $1.66 \mathrm{E}-04$ & 0.9874 & 8.31E-05 & 0.9380 & $6.65 \mathrm{E}-05$ & 0.9531 & $5.82 \mathrm{E}-05$ & 0.9764 \\
\hline A1.5 & 81.45 & 0.9984 & 48.05 & 0.9939 & 34.46 & 0.9962 & 34.88 & 1.0000 \\
\hline A2 & 58.98 & 0.9984 & 33.80 & 0.9928 & 23.65 & 0.9950 & 23.87 & 1.0000 \\
\hline A3 & 36.50 & 0.9982 & 19.54 & 0.9897 & 12.83 & 0.9907 & 12.86 & 0.9998 \\
\hline A4 & 25.26 & 0.9980 & 12.41 & 0.9846 & 7.42 & 0.9814 & $7 \cdot 36$ & 0.9992 \\
\hline \multicolumn{9}{|l|}{ Geometrical contraction models } \\
\hline $\mathrm{R} 2$ & 119.77 & 0.9998 & 69.31 & 0.9868 & 51.76 & 0.9909 & 51.24 & 0.9982 \\
\hline $\mathrm{R}_{3}$ & 121.92 & 0.9997 & 71.57 & 0.9906 & 53.15 & 0.9934 & 53.05 & 0.9992 \\
\hline \multicolumn{9}{|l|}{ Diffusion models } \\
\hline D1 & 242.89 & 0.9978 & 135.73 & 0.9750 & 104.55 & 0.9845 & 101.55 & 0.9942 \\
\hline D2 & 248.90 & 0.9990 & 142.93 & 0.9842 & 109.46 & 0.9901 & 107.91 & 0.9974 \\
\hline D3 & 255.71 & 0.9995 & 152.10 & 0.9921 & 115.12 & 0.9949 & 115.26 & 0.9995 \\
\hline D4 & 251.17 & 0.9993 & 145.94 & 0.9873 & 111.34 & 0.9920 & 110.34 & 0.9983 \\
\hline \multicolumn{9}{|l|}{ Reaction-order models } \\
\hline Fo/R1 & 113.79 & 0.9984 & 63.39 & 0.9705 & 47.87 & 0.9805 & 46.20 & 0.9924 \\
\hline $\mathrm{F} 1$ & 126.41 & 0.9985 & 76.56 & 0.9948 & 56.11 & 0.9971 & 56.89 & 1.0000 \\
\hline F2 & 25.05 & 0.9996 & 19.13 & 0.9979 & 17.43 & 0.9964 & 16.67 & 1.0000 \\
\hline$F_{3}$ & 159.18 & 0.9640 & 118.36 & 0.9226 & 78.03 & 0.9816 & 85.52 & 0.9798 \\
\hline
\end{tabular}


Leached + A

\begin{tabular}{|c|c|c|c|c|c|c|c|c|}
\hline \multirow{3}{*}{ Reaction Model } & \multicolumn{8}{|c|}{ Heating Rates $\left(\mathrm{K} \mathrm{min}^{-1}\right)$} \\
\hline & \multicolumn{2}{|c|}{10} & \multicolumn{2}{|c|}{20} & \multicolumn{2}{|c|}{30} & \multicolumn{2}{|c|}{50} \\
\hline & $\mathrm{Ea} \mathrm{kJ} \mathrm{mol}^{-1}$ & $\mathrm{R}^{2}$ & Ea kJ mol-1 & $\mathrm{R}^{2}$ & Ea kJ mol-1 & $\mathrm{R}^{2}$ & $\mathrm{Ea} \mathrm{kJ} \mathrm{mol}^{-1}$ & $\mathrm{R}^{2}$ \\
\hline \multicolumn{9}{|l|}{ Nucleation models } \\
\hline Po.7 & $8.31 \mathrm{E}-\mathrm{O} 4$ & 0.9624 & $4.16 \mathrm{E}-\mathrm{O} 4$ & 0.9266 & $4.16 \mathrm{E}-\mathrm{O} 4$ & 0.9861 & $2.49 \mathrm{E}-\mathrm{O} 4$ & 0.9984 \\
\hline $\mathrm{P} 2$ & $2.49 \mathrm{E}-\mathrm{O} 4$ & 0.9624 & $1.66 \mathrm{E}-04$ & 0.9266 & $1.66 \mathrm{E}-04$ & 0.9861 & $8.31 \mathrm{E}-\mathrm{O} 5$ & 0.9984 \\
\hline $\mathrm{P}_{3}$ & $1.66 \mathrm{E}-04$ & 0.9624 & $8.31 \mathrm{E}-05$ & 0.9266 & $8.31 \mathrm{E}-05$ & 0.9861 & $5.82 \mathrm{E}-\mathrm{O} 5$ & 0.9984 \\
\hline $\mathrm{P}_{4}$ & $1.66 \mathrm{E}-04$ & 0.9624 & $6.65 \mathrm{E}-05$ & 0.9266 & $7.48 \mathrm{E}-\mathrm{O} 5$ & 0.9861 & $4.99 \mathrm{E}-\mathrm{O} 5$ & 0.9984 \\
\hline A1.5 & 84.06 & 0.9957 & 40.44 & 0.9891 & 34.86 & 0.9206 & 23.02 & 0.9717 \\
\hline A2 & 60.89 & 0.9953 & 28.07 & 0.9867 & 23.90 & 0.9082 & 14.98 & 0.9645 \\
\hline A3 & 37.71 & 0.9943 & $15 \cdot 70$ & 0.9795 & 12.94 & 0.8717 & 6.95 & 0.9359 \\
\hline A4 & 26.12 & 0.9931 & 9.52 & 0.9662 & 7.46 & 0.8072 & 2.93 & 0.8374 \\
\hline \multicolumn{9}{|l|}{ Geometrical contraction models } \\
\hline R2 & 121.21 & 0.9893 & 58.01 & 0.9765 & 53.95 & 0.9341 & 35.26 & 0.9842 \\
\hline $\mathrm{R} 3$ & 124.16 & 0.9920 & 60.27 & 0.9824 & 54.87 & 0.9331 & 36.50 & 0.9818 \\
\hline \multicolumn{9}{|l|}{ Diffusion models } \\
\hline D1 & 234.80 & 0.9806 & 113.05 & 0.9617 & 111.57 & 0.9448 & 72.61 & 0.9921 \\
\hline D2 & 245.02 & 0.9870 & 120.41 & 0.9740 & 114.99 & 0.9432 & 77.11 & 0.9888 \\
\hline D3 & 256.97 & 0.9927 & 129.57 & 0.9853 & 118.72 & 0.9411 & 82.13 & 0.9847 \\
\hline $\mathrm{D} 4$ & 248.98 & 0.9891 & 123.42 & 0.9783 & 116.23 & 0.9426 & 78.78 & 0.9874 \\
\hline \multicolumn{9}{|l|}{ Reaction-order models } \\
\hline Fo/R1 & 113.08 & 0.9789 & 52.00 & 0.9537 & 51.29 & 0.9365 & 31.74 & 0.9906 \\
\hline $\mathrm{F} 1$ & 130.42 & 0.9961 & 65.18 & 0.9909 & 56.78 & 0.9306 & 39.09 & 0.9767 \\
\hline F2 & 25.27 & 0.9952 & 17.58 & 0.9977 & 16.99 & 0.9852 & 14.58 & 0.9966 \\
\hline $\mathrm{F}_{3}$ & 177.83 & 0.9786 & 105.08 & 0.9590 & 69.92 & 0.9067 & 57.46 & 0.9441 \\
\hline
\end{tabular}

